\title{
Diurnal In Vivo and Rapid In Vitro Effects of Estradiol on Voltage-Gated Calcium Channels in Gonadotropin-Releasing Hormone Neurons
}

\author{
Jianli Sun, Zhiguo Chu, and Suzanne M. Moenter \\ Departments of Medicine and Cell Biology, University of Virginia, Charlottesville, Virginia 22908
}

\begin{abstract}
A robust surge of gonadotropin-releasing hormone $(\mathrm{GnRH})$ release triggers the luteinizing hormone surge that induces ovulation. The GnRH surge is attributable to estradiol feedback, but the mechanisms are incompletely understood. Voltage-gated calcium channels (VGCCs) regulate hormone release and neuronal excitability, and may be part of the surge-generating mechanism. We examined VGCCs of GnRH neurons in brain slices from a model exhibiting daily luteinizing hormone surges. Mice were ovariectomized (OVX), and a subset was treated with estradiol implants $(\mathrm{OVX}+\mathrm{E})$. OVX $+\mathrm{E}$ mice exhibit negative feedback in the A.M. and positive feedback in the P.M. GnRH neurons express prominent high-voltage-activated (HVA) and small low-voltage-activated (LVA) macroscopic (whole-cell) Ca currents $\left(I_{\mathrm{Ca}}\right)$. LVA-mediated currents were not altered by estradiol or time of day. In contrast, in OVX +E mice, HVA-mediated currents varied with time of day; HVA currents in cells from OVX +E mice were lower than those in cells from OVX mice in the A.M. but were higher in the P.M. These changes were attributable to diurnal alternations in L- and N-type components. There were no diurnal changes in any aspect of HVA-mediated $I_{\mathrm{Ca}}$ in $\mathrm{OVX}$ mice. Acute in vitro treatment of cells from $\mathrm{OVX}$ and $\mathrm{OVX}+\mathrm{E}$ mice with estradiol rapidly increased HVA currents primarily through L- and R-type VGCCs by activating estrogen receptor $\beta$ and GPR30, respectively. These results suggest multiple mechanisms contribute to the overall feedback regulation of HVA-mediated $I_{\mathrm{Ca}}$ by estradiol. In combination with changes in synaptic inputs to GnRH neurons, these intrinsic changes in GnRH neurons may play critical roles in estradiol feedback.
\end{abstract}

\section{Introduction}

Gonadotropin-releasing hormone (GnRH) neurons form the final common pathway by which the CNS regulates fertility (Wildt et al., 1980). GnRH is released in a pulsatile pattern critical for secretion of gonadotropic hormones by the pituitary in both sexes, and in a surge mode of continuous release that triggers ovulation in females (Karsch et al., 1992). In females, these two modes of release are differentially regulated by estradiol negative and positive feedback, respectively. In rodents, estradiol interacts with a circadian signal so that the luteinizing hormone surge occurs at a specific time of day (Norman et al., 1973; Legan and Karsch, 1975; Christian et al., 2005). Although progress has been made in understanding synaptic mechanisms underlying surge generation (Miller et al., 2006; Dungan et al., 2007; Christian and Moenter, 2008b; Clarkson et al., 2008), intrinsic mechanisms are not well understood.

Calcium entry mediated by voltage-gated calcium channels (VGCCs) triggers a wide array of cellular responses ranging from muscle contraction and activation of calcium-dependent en-

Received Dec. 17, 2009; revised Feb. 1, 2010; accepted Feb. 3, 2010.

This work was supported by National Institutes of Health-Eunice Kennedy Shriver National Institute of Child Health and Human Development Grants R01 HD41469 and R01 HD34860. We thank Debra Fisher for expert technical assistance, Dr. Yi Zhang from Baylor College of Medicine for scientific advice, and Peilin Chen, Alison Roland, Pei-San Tsai, and R. Anthony DeFazio for helpful editorial comments.

Correspondence should be addressed to Suzanne M. Moenter, P.0. Box 800578, University of Virginia, Charlottesville, VA 22908. E-mail: moenter@virginia.edu.

DOI:10.1523/JNEUROSCI.6256-09.2010

Copyright $\odot 2010$ the authors $\quad 0270-6474 / 10 / 303912-12 \$ 15.00 / 0$ zymes, to calcium-triggered exocytosis (Batra, 1987; Jarvis and Zamponi, 2007). High-voltage-activated (HVA) VGCCs require substantial depolarization to open, whereas low-voltage-activated (LVA) VGCCs open at more hyperpolarized potentials near the resting potential. The role of VGCCs in regulating excitability and secretion makes them candidates for altering GnRH neuron activity during different estradiol feedback states. Estrogens modulate calcium channel activity and expression in muscle and other neurons via direct and indirect mechanisms (Batra, 1987; Joëls and Karst, 1995; Johnson et al., 1997; Patterson et al., 1998; Kurata et al., 2001; Lee et al., 2002; Ullrich et al., 2007; Sarkar et al., 2008). There are few studies of VGCCs in GnRH neurons and fewer that consider changes in current through these channels with physiological state. Calcium currents in GnRH neurons have been studied in mouse embryonic olfactory placode cultures (Kusano et al., 1995), immortalized GnRH neurons (GT1-7 cells) (Bosma, 1993; Hiruma et al., 1997; Van Goor et al., 1999, 2000; Krsmanović et al., 2001; Watanabe et al., 2004), acutely dissociated GnRH neurons (Kato et al., 2003; Nunemaker et al., 2003b), and teleost and mouse brain slices (Haneda and Oka, 2004; Spergel, 2007). The current subtypes detected were dependent on both species and developmental stage. Although other studies suggest calcium channels are important for GnRH neuron function (Bourguignon et al., 1987; Krsmanović et al., 1992; Giri and Kaufman, 1994; Fukushima et al., 2003) and that estradiol might modulate their activity (Temple et al., 2004; Abe et al., 2008), the physiological regulation of calcium currents in these cells has not been studied beyond gross developmental changes. 
Estradiol can act via multiple mechanisms (Nilsson et al., 2001; Edwards, 2005; Woolley, 2007). To better understand the mechanism of estradiol feedback on GnRH neurons, we tested how both in vivo estradiol, in an animal model exhibiting daily switches between estradiol negative and positive feedback (Christian et al., 2005), and acutely applied in vitro estradiol alter VGCCs. The data suggest estradiol and diurnal signals converge to modulate VGCCs on GnRH neurons.

\section{Materials and Methods}

Animals. Adult female mice (2-3 months) expressing eGFP (enhanced green fluorescent protein) (Clontech) under the control of the $\mathrm{GnRH}$ promoter were used to facilitate identification of GnRH neurons (Suter et al., 2000a). Mice were maintained under a 14/10 h light/dark photoperiod with Harlan 2916 chow (Harlan) and water available ad libitum. Mice were ovariectomized (OVX) under isoflurane (Abbott Laboratories) anesthesia to remove ovarian steroid feedback; some OVX mice received steroid implants containing $0.625 \mu \mathrm{g}$ of $17 \beta$-estradiol in sesame oil $(\mathrm{OVX}+\mathrm{E})$, which produce physiological levels of estradiol in the circulation as previously described (Christian et al., 2005). 17 $\beta$-Estradiol was administered in vivo and was not present in any recording solutions except for specific studies of the rapid effects of estradiol, in which case the steroid was applied acutely in vitro as described below. Postoperative analgesia was provided by a long-acting local anesthetic ( $0.25 \%$ bupivicaine; $7.5 \mu \mathrm{l} /$ site; Abbott Laboratories). Recordings were made $2-5 \mathrm{~d}$ after surgery and steroid replacement. All animal procedures were approved by the University of Virginia Animal Care and Use Committee.

Brain slice preparation. All chemicals were obtained from SigmaAldrich unless noted. Brain slices were prepared as previously described (Nunemaker et al., 2002; Chu and Moenter, 2005). Briefly, mice were killed at times that corresponded to negative feedback (8:30-9:30 A.M.; referred to as A.M.) or surge peak (positive feedback; 1:30-2:30 P.M.; referred to as P.M.) in estradiol-treated animals. The brain was rapidly removed and placed in ice-cold high-sucrose saline solution containing the following (in $\mathrm{mm}$ ): 250 sucrose, $3.5 \mathrm{KCl}, 26 \mathrm{NaHCO}_{3}, 10 \mathrm{D}$-glucose, $1.25 \mathrm{Na}_{2} \mathrm{HPO}_{4}, 1.2 \mathrm{MgSO}_{4}, 2.5 \mathrm{MgCl}_{2}$. Coronal $(300 \mu \mathrm{m})$ slices were cut with a Vibratome 3000 (Ted Pella). Slices were incubated for $30 \mathrm{~min}$ at $30-32^{\circ} \mathrm{C}$ in $50 \%$ high-sucrose saline and $50 \%$ artificial CSF (ACSF) solution, containing the following (in $\mathrm{mm}$ ): $135 \mathrm{NaCl}, 3.5 \mathrm{KCl}, 26$ $\mathrm{NaHCO}_{3}, 10$ D-glucose, $1.25 \mathrm{Na}_{2} \mathrm{HPO}_{4}, 1.2 \mathrm{MgSO}_{4}, 2.5 \mathrm{CaCl}_{2}, \mathrm{pH}$ 7.4. Slices were then transferred to $100 \%$ ACSF solution at room temperature $\left(\sim 21-23^{\circ} \mathrm{C}\right)$ for $0.5-2.5 \mathrm{~h}$. For recording, slices were placed in a recording chamber on the stage of an Olympus BX51WI upright fluorescent microscope and continuously superfused at 5-6 $\mathrm{ml} / \mathrm{min}$ with oxygenated ACSF at 25 or $32^{\circ} \mathrm{C}$ as described below. Slices were stabilized in the chamber for $\geq 5$ min before recording.

Electrophysiological recording. GFP-GnRH neurons in the preoptic area were identified by brief illumination at $470 \mathrm{~nm}$. Macroscopic $\mathrm{Ca}^{2+}$ currents from GnRH neurons were recorded using the whole-cell configuration of the patch-clamp technique. Patch pipettes (2.5-3.5 M 2 ) were drawn from borosilicate glass capillaries $(1.65 \mathrm{~mm}$ outer diameter; $1.12 \mathrm{~mm}$ inner diameter; World Precision Instruments) using a Sutter P97 pipette puller. Electrode capacitance was electronically compensated. Liquid junction potential (less than $-4 \mathrm{mV}$ for voltage clamp and approximately $-13 \mathrm{mV}$ for current clamp) was not corrected (Barry, 1994). Currents and voltages were recorded with an Axopatch-700B amplifier (Molecular Devices) and filtered at $10 \mathrm{kHz}$. Voltage and current command pulses were generated using pCLAMP9.2 software (Molecular Devices). Neuron membrane potential was held at $-60 \mathrm{mV}$ between protocols during voltage-clamp recordings. During whole-cell recording, input resistance $\left(R_{\mathrm{in}}\right)$, series resistance $\left(R_{\mathrm{s}}\right)$, and membrane capacitance $\left(C_{\mathrm{m}}\right)$ were continually monitored. Only recordings with $R_{\text {in }}>500$ $\mathrm{M} \Omega, R_{\mathrm{s}}<20 \mathrm{M} \Omega$, and $C_{\mathrm{m}}>10 \mathrm{pF}$, and holding current between 0 and $-50 \mathrm{pA}$ were included for analysis. There were no differences among groups in any passive recording properties or series resistance attributable to steroid treatment or time of day or response to treatment. Cells with bad clamping (identified as sluggish, incomplete current response to pulse protocol, and/or $10-90 \%$ rise time $>2.5 \mathrm{~ms}$ ) were discarded.
Recordings were performed from 1 to $3 \mathrm{~h}$ after preparation of brain slices was complete. No more than four cells per animal were recorded. Recorded cells were mapped to an atlas (Paxinos and Franklin, 2001) to determine whether any trends based on anatomical location emerged; no such trends were apparent in these data sets (data not shown).

Drugs and solutions. For voltage-clamp recording of $I_{\mathrm{Ca}}$, the bath solution consisted of the following (in $\mathrm{mm}$ ): $120 \mathrm{NaCl}, 10$ glucose, 26 $\mathrm{NaHCO}_{3}, 1.25 \mathrm{Na}_{2} \mathrm{HPO}_{4}, 1.2 \mathrm{MgSO}_{4}, 2.5 \mathrm{CaCl}_{2}, 5$ 4-aminopyridine (4AP), $5 \mathrm{CsCl}, 10$ tetraethylammonium (TEA)-Cl, and 0.0005 TTX, pH 7.4 (gassed with $95 \% \mathrm{O}_{2}$ and $5 \% \mathrm{CO}_{2}$ ); the pipette solution contained the following (in mM): 120 Cs-gluconate, 10 HEPES, 10 EGTA, $0.5 \mathrm{CaCl}_{2}, 4 \mathrm{Mg}$-ATP, $0.4 \mathrm{NaGTP}$, and 20 TEA-Cl, pH 7.3 (titrated with $\mathrm{CsOH}, 310 \mathrm{mOsm}$ ). For current-clamp recording, ACSF was used for bath solution; the pipette solution contained the following (in $\mathrm{mM}$ ): $125 \mathrm{~K}$-gluconate, $20 \mathrm{KCl}, 10 \mathrm{HEPES}, 5 \mathrm{EGTA}, 4.0 \mathrm{MgATP}, 0.4 \mathrm{NaGTP}$, $0.1 \mathrm{CaCl}_{2}, \mathrm{pH} 7.3,290 \mathrm{mOsm}$. Bicuculline $(20 \mu \mathrm{M})$, APV [D-(-)-2amino-5-phosphonovaleric acid] $(20 \mu \mathrm{M})$, and CNQX (6-cyano-7nitroquinoxaline) $(10 \mu \mathrm{M})$ were included in the bath solution to block ionotropic GABAergic and glutamatergic currents. Nitrendipine (50 $\mu \mathrm{M})$, agatoxin IVA (166 nM), conotoxin GVIA (700 nM), estradiol $17 \beta$ (100 pm to $100 \mathrm{~nm})$, estradiol $17 \alpha(100 \mathrm{~nm})$, the estrogen $\alpha$ receptor agonist 1,3,5-tris(4-hydroxyphenyl)-4-propyl-1 $H$-pyrazole (PPT) (10 $\mathrm{nM}), \beta$ receptor agonist 2,3-bis(4-hydroxyphenyl)propionitrile (DPN) $(10 \mathrm{nM})$, the estrogen receptor (ER) antagonist $7 \alpha, 17 \beta-[9[(4,4,5,5,5-$ pentafluoropentyl)sulfinyl] nonyl] estra-1,3,5(10)-triene-3,17-diol (ICI 182780) (1 $\mu \mathrm{M})$, GPR30 agonist G1 (100 nM), cadmium chloride (200 $\mu \mathrm{M})$, and nickel chloride (100 $\mu \mathrm{M}$ or $1 \mathrm{mM}$ ) were bath applied; SNX-482 $(1 \mu \mathrm{M})$ was locally applied by pressure micropipette.

Voltage-clamp protocols. All currents were corrected for leak and capacitive currents on-line by a $\mathrm{P} /-6$ protocol. To generate $\mathrm{Ca}^{2+}$ channel current-voltage $(I-V)$ activation curves, currents were elicited by a voltage protocol of a $250 \mathrm{~ms}$ prepulse at $-120 \mathrm{mV}$ to remove inactivation, followed by current measurement at test potentials $(250 \mathrm{~ms})$ from -80 to $+60 \mathrm{mV}$ at $10 \mathrm{mV}$ increments. To determine the steady-state inactivation of calcium currents, the membrane potential was initially hyperpolarized to $-100 \mathrm{mV}$ for $500 \mathrm{~ms}$ to remove inactivation, followed by a $1 \mathrm{~s}$ prepulse of -100 to $10 \mathrm{mV}$ in $10 \mathrm{mV}$ increments, and then a test pulse of $10 \mathrm{mV}$ for $500 \mathrm{~ms}$; current was quantified during the test pulse. Both of these protocols were done at $32^{\circ} \mathrm{C}$ and at $25^{\circ} \mathrm{C}$ in separate slices to determine the effect of temperature. Several different voltage protocols were used to examine LVA currents, which were recorded at $32^{\circ} \mathrm{C}$ to maximize amplitude. To isolate LVA currents by subtraction, separate voltage protocols of a $250 \mathrm{~ms}$ prepulse at either -100 or $-50 \mathrm{mV}$, were followed by test potentials $(250 \mathrm{~ms})$ from -80 to $+60 \mathrm{mV}$ at $10 \mathrm{mV}$ increments. To isolate LVA currents by selective activation, a $1 \mathrm{~s}$ prepulse at $-100 \mathrm{mV}$ was followed by a $250 \mathrm{~ms}$ test pulse at $-50 \mathrm{mV}$. To examine tail currents, channels were activated by a step from prepulse at $-100 \mathrm{mV}(250 \mathrm{~ms})$ to $10 \mathrm{mV}$ for $10 \mathrm{~ms}$, followed by a step to $-60 \mathrm{mV}$ for determination of tail current kinetics.

To examine subtypes of HVA currents contributing to the macroscopic current and the effects of in vivo and in vitro estradiol treatment on these currents, recordings were done at $25^{\circ} \mathrm{C}$ to minimize rundown. After 3-5 min stabilization, a voltage protocol consisting of a prepulse at $-100 \mathrm{mV}$ for $250 \mathrm{~ms}$ followed by a step for $250 \mathrm{~ms}$ to $+10 \mathrm{mV}$ (peak of $I V$ response curve) was repeated every $30 \mathrm{~s}$ to determine peak and sustained current. These measures were made during a 5 min control period, followed by a 10-15 min bath application of specific VGCC blockers, vehicle, $17 \alpha$-estradiol, $17 \beta$-estradiol, or estradiol receptor antagonists and agonists, followed by a $10 \mathrm{~min}$ washout period. Nitredipine was applied for $20 \mathrm{~min}$ with no washout.

Analysis. The peak amplitude and the sustained amplitude $200 \mathrm{~ms}$ after the beginning of test potential were calculated. Current waveforms were fitted with the Clampfit program (Molecular Devices) or GraphPad Prism program (GraphPad Software). The voltage dependencies of activation and steady-state inactivation were described with a single Boltzmann distribution: $I(V)=I_{\max } /\left(1+\exp \left[\left(V_{1 / 2}-V\right) / k\right]\right)$, where $I_{\max }$ is the maximal current elicited, $V_{1 / 2}$ is the half-maximal voltage, and $k$ is the voltage dependence (slope) of the distribution. The time course of tail current was fit by two exponentials function with Igor Pro (Wavemet- 
rics). For all current-voltage $(I-V)$ curves and steady-state inactivation curves, fitted values were typically reported with $95 \%$ linear confidence limits.

To isolate LVA currents, the current recorded after a $-50 \mathrm{mV}$ prepulse was subtracted from that recorded after the $-100 \mathrm{mV}$ prepulse, or repeated 50 times to reduce noise level with the $1 \mathrm{~s}-100 \mathrm{mV}$ prepulse protocol. To isolate different subtype VGCCs, the first $5 \mathrm{~min}$ of recording under control conditions from each cell was fitted to determine the rundown rate; average effects of blockers were subtracted from the rundown rate at 11-15 $\mathrm{min}$ (in vivo) or 16-20 min (in vitro) after applications from the theoretical rundown line. The R-type component (in vivo) was corrected for a small (6$7 \%$ ) artifact that was observed in the macroscopic current after pressure applying bath solution. Control $I_{\mathrm{Ca}}$ variations was $<4 \% 15-20 \mathrm{~min}$ into the recording. Cells were considered to respond to estradiol if $I_{\mathrm{Ca}}$ changed by $\geq 20 \%$.

Parametric and nonparametric analyses were performed in Prism as dictated by data distribution. Statistical comparisons of in vivo treatments were done with ANOVA followed by Bonferroni's post hoc test. Two-tailed paired comparisons of current before and after in vitro treatments were done with each cell serving as its own control. Statistical significance was set at $p<0.05$. The data shown represent mean $\pm \mathrm{SEM}$.

\section{Results}

Adult GnRH neurons in brain slice express a small LVA macroscopic Ca current, which is not affected by estradiol in vivo

Electrophysiological assessment of calcium currents in various $\mathrm{GnRH}$ neuronal model systems has led to different conclusions as to the expression of LVA versus HVA currents. We thus first characterized the macroscopic calcium current in acutely prepared brain slices from adult OVX mice. Under our recording conditions, all GnRH neurons displayed prominent HVA currents, activating positive to a membrane potential of $-40 \mathrm{mV}$, and reaching maximum amplitude around $+10 \mathrm{mV}$ (Fig. $1 A, C, D)$; this current was blocked with the nonspecific Ca channel blocker cadmium (data not shown). However, none of the 121 neurons recorded from OVX mice had measurable currents activating negative to $-40 \mathrm{mV}$ using this protocol. In contrast, non-GnRH neurons recorded in the same slices ( $n=$ 17) displayed prominent currents activated at $-60 \mathrm{mV}$ (Fig. $1 B-D)(n=17)$, which were rapidly inactivated as is characteristic of T-type LVA currents. Thus, prominent LVA currents could be detected by this protocol under these recording conditions.

We next attempted to reveal LVA-mediated currents in GnRH neurons using a subtraction protocol. Current recorded after a $-50 \mathrm{mV}$ prepulse, which should inactivate LVA channels, was subtracted from current recorded after a $-100 \mathrm{mV}$ prepulse, ${ }^{*} p<0.05$; ${ }^{* *} p<0.01$.

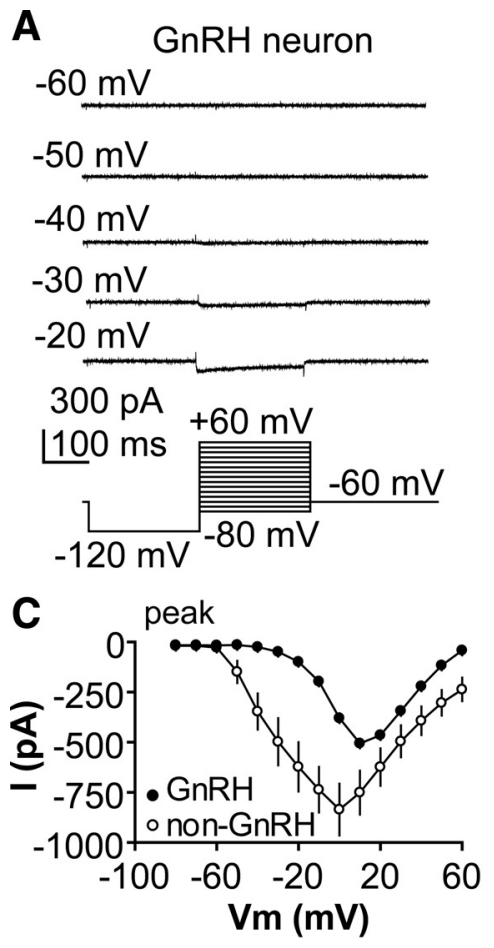

\begin{tabular}{l} 
B non-GnRH neuron \\
$-60 \mathrm{mV}$ \\
\hline
\end{tabular}
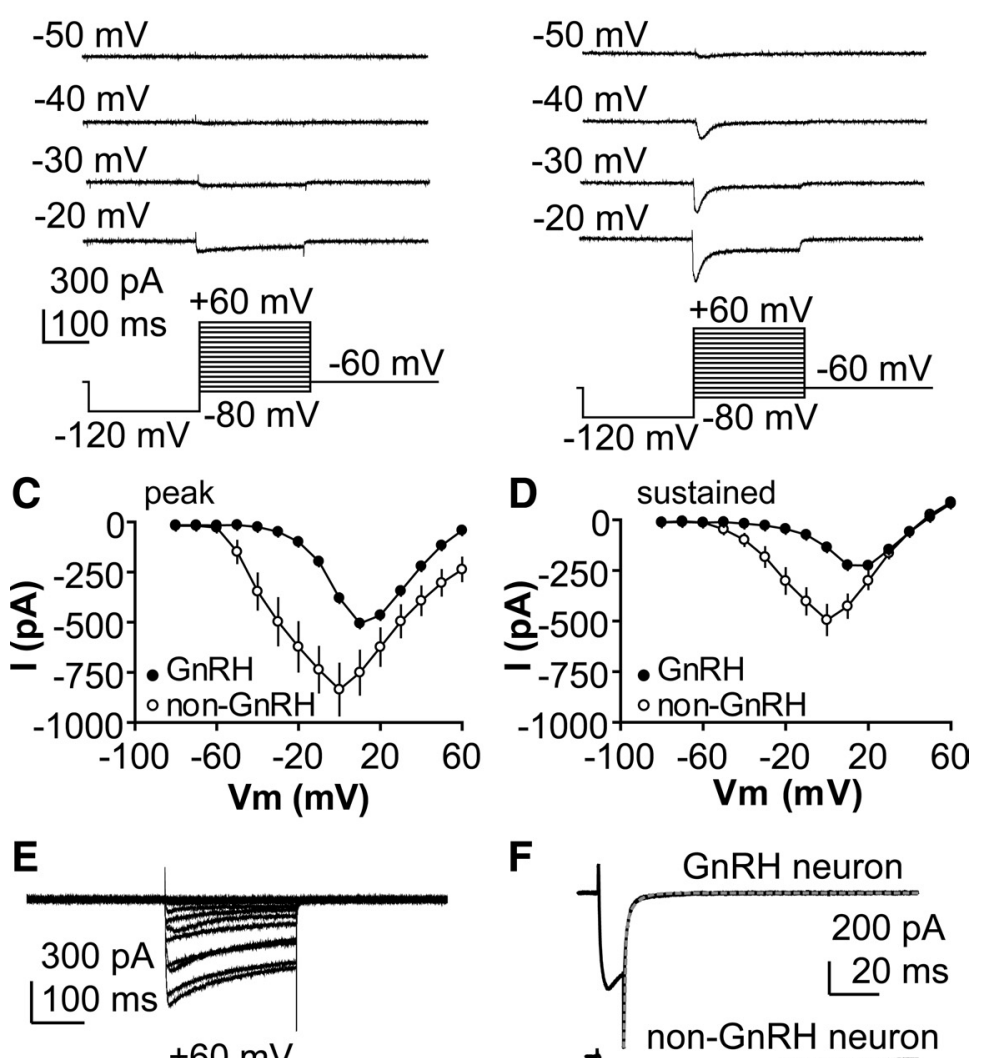

F
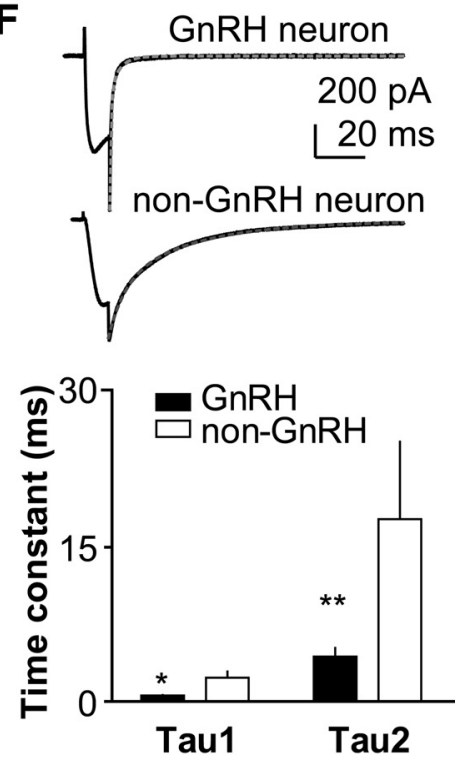

Figure 1. Adult $G n R H$ neurons exhibit limited LVA calcium current. $\boldsymbol{A}, \boldsymbol{B}$, Representative of calcium current recorded at different membrane potentials in $\mathrm{GnRH}$ and non-GnRH neuron, respectively. $\boldsymbol{C}, \boldsymbol{D}$, Average current-voltage curves of peak and sustained current from GnRH and non-GnRH neurons. $\boldsymbol{E}$, Subtraction of calcium current recorded with a $-50 \mathrm{mV}$ prepulse from current recorded with a $-100 \mathrm{mV}$ prepulse does not reveal LVA-mediated current. $\boldsymbol{F}$, Representative tail current and time course of tail current ( $\tau_{1}$ and $\tau_{2}$ ) from GnRH neuron (top) and non-GnRH neuron (middle), and mean \pm SEM time constants (bottom).

which should remove inactivation from LVA channels. Again, minimal LVA current is observed in GnRH neurons using this approach (Fig. $1 E)(n=8)$. We next examined tail currents, which are of longer duration for LVA than HVA channels. Tail currents in GnRH neurons were of short duration $\left(\tau_{1}, 0.56 \pm\right.$ $0.05 \mathrm{~ms} ; \tau_{2}, 4.31 \pm 0.84 \mathrm{~ms} ; n=12$ ), consistent with a predominance of HVA channels. In contrast, tail currents in random non-GnRH neurons were prolonged $\left(\tau_{1}, 2.28 \pm 0.60 \mathrm{~ms}, n=17\right.$, $p<0.05 ; \tau_{2}, 17.54 \pm 2.79 \mathrm{~ms}, n=17, p<0.01$ ) (Fig. $1 F$ ), indicating the presence of LVA channels. 

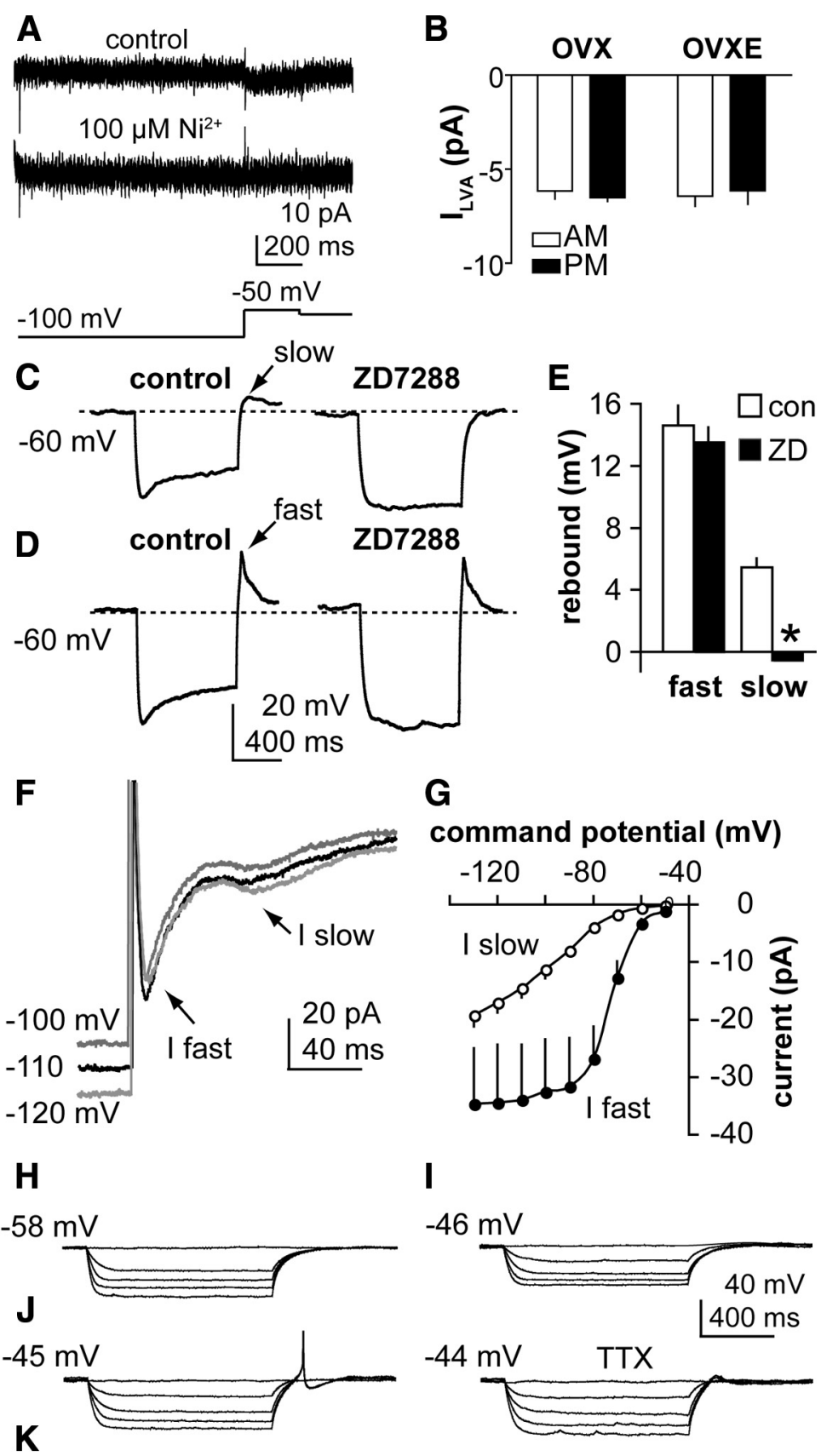

\section{I}
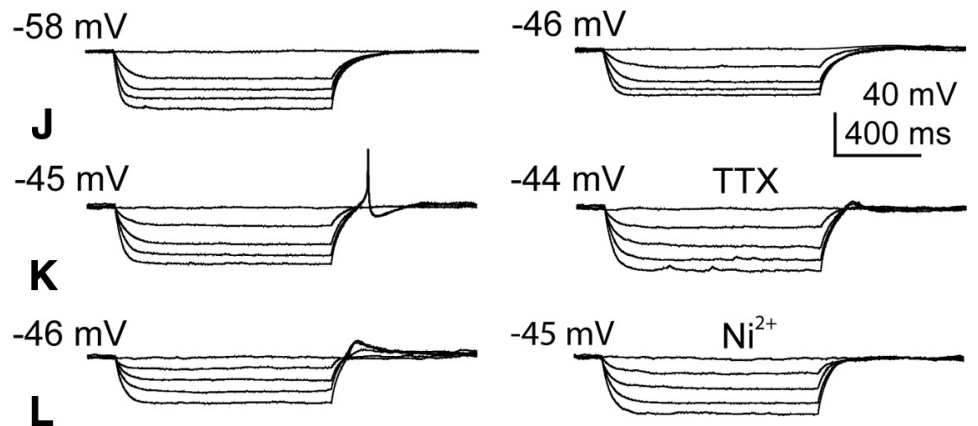

$-60 \mathrm{mV}$

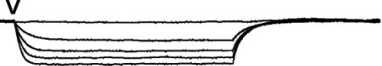

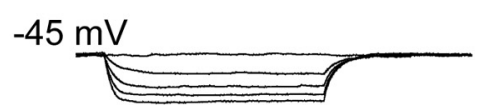

Figure 2. LVA-mediated currents function in GnRH neurons but are not altered in a diurnal model of estradiol positive and negative feedback. $A$, Representative average of 50 repeats of a voltage protocol to reveal LVA current (top) and its blockade by $\mathrm{Ni}^{2+}$. B, LVA-mediated current does not change with estradiol or time of day in this model. Error bars indicate SEM. $\mathbf{C}-\mathbf{G}$, Differentiation of fast and slow rebound potential and current in GnRH neurons. $\boldsymbol{C}, \boldsymbol{D}$, Representative current-clamp recordings of the slow $(\boldsymbol{C})$ and fast $(\boldsymbol{D})$ rebound potential generated by termination of a $50 \mathrm{pA}$ hyperpolarizing current injection. $\boldsymbol{E}, \mathrm{ZD7} 288$ (right) inhibits the slow but not the fast rebound potential $(p<0.05)$. $\boldsymbol{F}$, Voltage-clamp recording of a cell exhibiting both fast and slow rebound current. Cell was stepped from a holding potential of $-50 \mathrm{mV}$ to the potentials indicated on the left for $1.2 \mathrm{~s}$, and then returned to $-50 \mathrm{mV}$. G, Voltage dependence of the slow (open symbols) and fast (closed symbols) rebound current. $\boldsymbol{H}$, Representative current-clamp recording of GnRH neuron with a resting potential near the average and that did not exhibit rebound depolarization. I, Representative example of a GnRH neuron with a depolarized resting potential that did not exhibit rebound depolarization. J, Left, Representative current-clamp recording of a GnRH neuron with a depolarized resting potential that exhibited a rebound potential after termination of hyperpolarizing current injections. In this example, the rebound potential contributes

Finally, we used averaging to increase the signal-to-noise ratio. A prolonged (1 s) prepulse at $-100 \mathrm{mV}$ was given to provide a strong signal to remove inactivation, and then the membrane potential was stepped to $-50 \mathrm{mV}$; this protocol was repeated 50 times at $30 \mathrm{~s}$ intervals and the resulting current traces averaged. Under these conditions, $41 \%$ of GnRH neurons exhibit a small amplitude LVA-mediated current $(6.5 \pm 0.2 \mathrm{pA}$ in cells from OVX mice; $n=15$ ) (Fig. $2 A, B$ ) that was blocked by $100 \mu \mathrm{M} \mathrm{Ni}{ }^{2+}(n=13$ cells $)$ (Fig. $2 A$ ). It is possible that LVA currents activated by this protocol or other protocols would be masked by large outward A-type potassium currents that are typical of GnRH neurons (DeFazio and Moenter, 2002; Zhang et al., 2007, 2009b). Neither the percentage of GnRH neurons exhibiting LVA current nor amplitude of this current was altered by the A-type potassium current blocker 4AP $(n=7)$ (data not shown), suggesting this compound did not contribute to the failure to detect LVA current in the previous attempts. Cadmium $(200 \mu \mathrm{M})$ reduced the percentage of $\mathrm{GnRH}$ neurons exhibiting this current but did not eliminate it $(n=10)$ (data not shown). The ability of cadmium to block channels is voltage dependent, with blocking ability decreasing at more hyperpolarized potentials (Swandulla and Armstrong, 1989). Together, these data suggest a subpopulation of adult GnRH neuron expresses small LVA currents as measurable by recordings at the cell soma.

To study the effect of estradiol on LVA channels, we compared the current measured using the averaging protocol (Fig. 2A) among GnRH neurons from OVX and OVX $+\mathrm{E}$ mice recorded at different times of day (Fig. 2B). The peak amplitude of LVA current was not different among groups (OVX A.M., $n=7$; OVX P.M., $n=8$; OVX+E A.M., $n=10$; OVX+E P.M., $n=10 ; p>0.1)$. These data suggest estradiol in vivo does not alter LVA-mediated currents in GnRH neurons in this model of steroid replacement.

GnRH neurons typically have input resistance near $1 \mathrm{G} \Omega$; thus, even relatively small currents such as the LVA currents measured here can impact the physiology of these cells. To assess whether LVA-

$\leftarrow$

to action potential generation, which is blocked by TTX (right). $\boldsymbol{K}$, Nickel $(100 \mu \mathrm{M})$ completely blocked the rebound potential in GnRH neurons. L, Depolarizing GnRH neurons (right) that exhibit hyperpolarized resting membrane potential does not induce rebound potential. 
mediated current contributes to GnRH neuron activity, we used current clamp to investigate the rebound in membrane potential after hyperpolarization. Rebound depolarizations can be generated by activation of either LVA-mediated or hyperpolarization-activated nonspecific cation $(\mathrm{HCN})$-mediated currents $\left(I_{\mathrm{h}}\right)$ during a preceding membrane hyperpolarization. To differentiate between rebound potentials mediated by LVA versus $\mathrm{HCN}$ channels, latency to peak of the response and sensitivity to the $I_{\mathrm{h}}$ blocker 4-ethylphenylamino-1,2-dimethyl-6-methylaminopyrimidinium chloride (ZD7288) $(50 \mu \mathrm{M})$ were determined. After hyperpolarization in current clamp, GnRH neurons exhibit two types of rebound potentials, slow (Fig. $2 C$ ) and fast (Fig. 2D). ZD7288 has no effect on the fast rebound but eliminates the slow rebound $(n$ $=11, p<0.05)$ (Fig. $2 C-E$ ). In voltage clamp, a greater degree of hyperpolarization is required to activate the slow current (latency to peak of current, $97.4 \pm 4.2$ $\mathrm{ms}$ ) on return to $-50 \mathrm{mV}$ than the fast current (latency to peak of current, $22.5 \pm$ $2.8 \mathrm{~ms}$ ) (Fig. $2 F, G$ ). Furthermore, the activation of the fast current reaches a plateau by approximately $-100 \mathrm{mV}$, whereas greater hyperpolarization further increases the slow current. Finally, $\sim 50 \%$ of cells exhibit the slow current, which is blocked by the specific $I_{\mathrm{h}}$ blocker ZD7288 (Z. Chu, H. Takagi, and S. M. Moenter, unpublished data), and thus distinguished from the LVA-mediated rebound discussed below. Together, these data demonstrate that we can distinguish between fast and slow rebound currents that are likely mediated by LVA and HCN channels, respectively.

To reveal rebound potentials, hyperpolarizing current steps $(10-40 \mathrm{pA} ; 1 \mathrm{~s})$ were injected, and depolarization relative to initial membrane potential ("rebound") was quantified. A total of 73 cells with an average resting potential $\left(V_{\text {rest }}\right)$ of $-57.6 \pm 1.0 \mathrm{mV}$ was examined. Most cells $(n=55)$ exhibited $V_{\text {rest }}$ that was more hyperpolarized than $-50 \mathrm{mV}$ and none of these cells exhibited a depolarizing rebound of membrane potential after termination of a hyperpolarizing current injection (Fig. $2 H$ ). A smaller subpopulation exhibited $V_{\text {rest }}$ that was depolarized to $-50 \mathrm{mV}(46.3 \pm 1.4 \mathrm{mV} ; n=18)$. Of these depolarized cells, approximately one-half ( 8 of 18 ) were similar to the more hyperpolarized cells as they exhibited no rebound depolarization (Fig. 2 I). In contrast, the other one-half ( 10 of 18 cells) exhibited a rebound depolarization $(10.4 \pm 1.0 \mathrm{mV})$ after a $40 \mathrm{pA}$ hyperpolarizing current injection (bringing membrane potential to $-85.2 \pm 1.0 \mathrm{mV}$ ) that could result in action potential generation that was blocked by TTX (Fig. $2 J$ ). The time to peak of the rebound potential from the end of hyperpolarizing current $\mathrm{OVX}+\mathrm{E}$ mice in the A.M. and P.M.
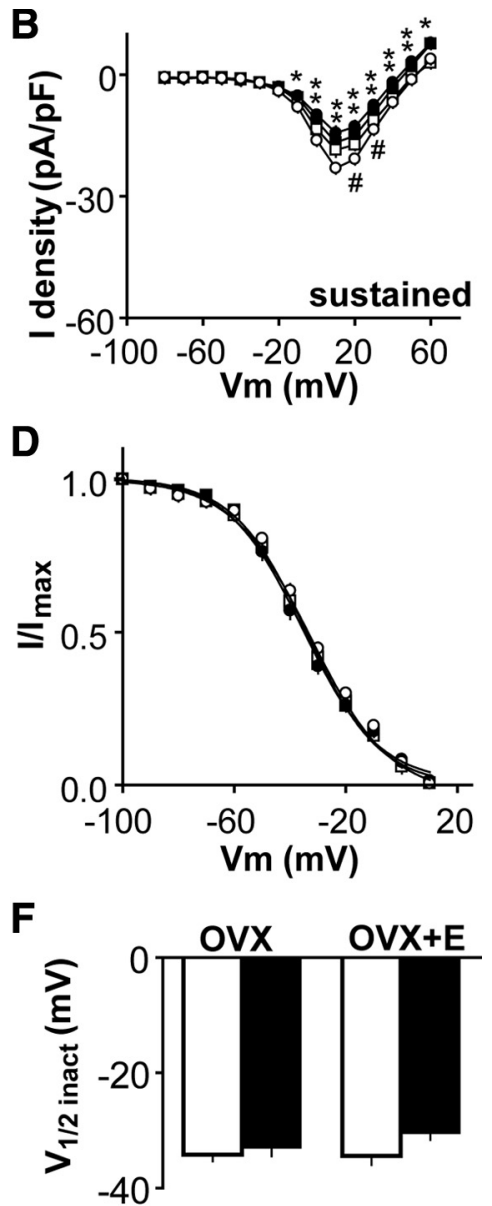
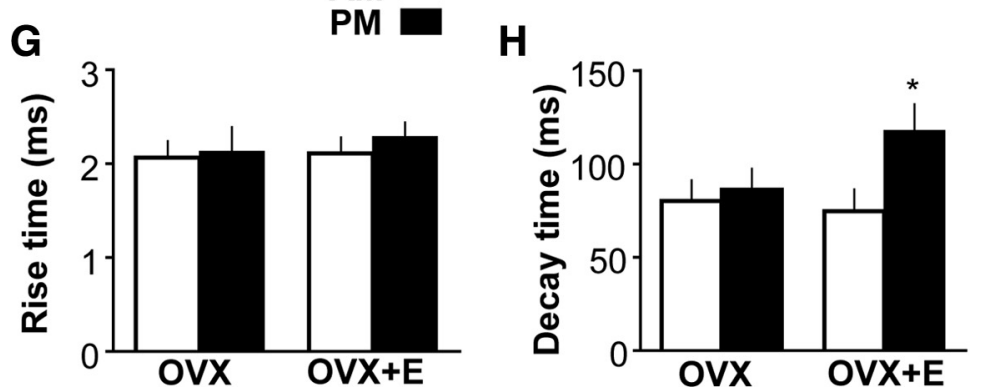

Figure 3. HVA-mediated $I_{\mathrm{Ca}}$ in GnRH neurons is modulated in an estradiol-dependent diurnal manner. $\boldsymbol{A}, \boldsymbol{B}$, Currentvoltage plots of peak and sustained current density from $0 \mathrm{VX}$ and $\mathrm{OVX}+\mathrm{E}$ mice in the A.M. and P.M. $\left[{ }^{*} p<0.05,0 \mathrm{VX}\right.$ vs OVX+E in the A.M.; ${ }^{\#} p<0.05,0 V X$ vs OVX+E in the P.M.; ${ }^{* *} p<0.01,0 V X+E$ A.M. vs OVX+E P.M. (not marked in $A$ as all values are significant)]. $C, D, A c t i v a t i o n$ and steady-state inactivation curves from $0 V X$ and $O V X+E$ mice in the A.M. and P.M. $\boldsymbol{E}-\boldsymbol{H}$, Mean \pm SEM $V_{1 / 2 \text { act }}(\boldsymbol{E}), V_{1 / 2 \text { inact }}(\boldsymbol{F})$, rise time $(10-90 \%)(\boldsymbol{G})$, and decay time $(90-50 \%)(\boldsymbol{H})$ from $0 \mathrm{VX}$ and

injection was $110.7 \pm 2.4 \mathrm{~ms}$, and the decay time was $130.1 \pm 5.5$ ms. This rebound depolarization was blocked by $\mathrm{Ni}^{2+}(100 \mu \mathrm{M})$, suggesting it may be mediated by LVA channels (Fig. $2 \mathrm{~K}$ ). Hyperpolarization of these cells to $-54.0 \pm 0.8 \mathrm{mV}$ by DC current injection $(5 \mathrm{pA})$ reduced the amplitude of the rebound $(4.9 \pm$ $0.6 \mathrm{mV} ; n=6 ; p<0.05$ ) (data not shown). In contrast, depolarization of the majority of GnRH neurons that exhibited more hyperpolarized $V_{\text {rest }}$ to $43.1 \pm 1.3 \mathrm{mV}$ did not generate a rebound depolarization $(n=20)$ (Fig. $2 L)$. These results suggest that, in GnRH neurons, rebound current is dependent on the resting membrane potential, and LVA can contribute to the function of a subpopulation of GnRH neurons. 
A

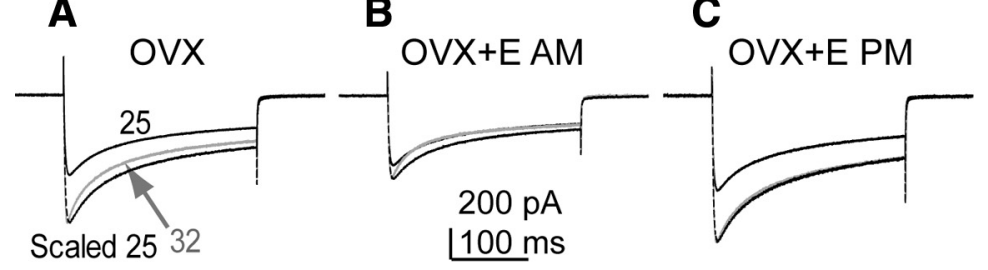

D

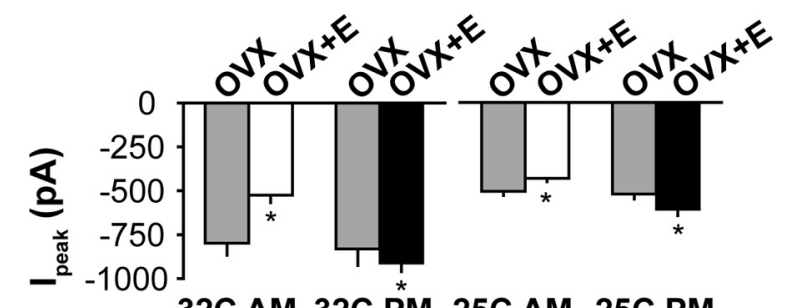

E

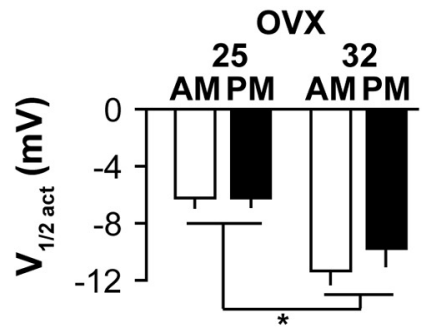

$\mathbf{F}$

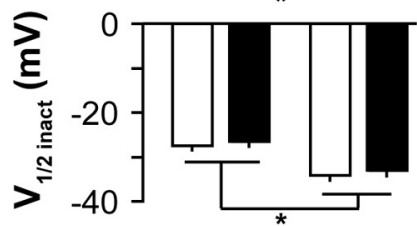

G

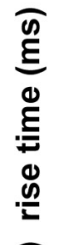

$\mathbf{H}$

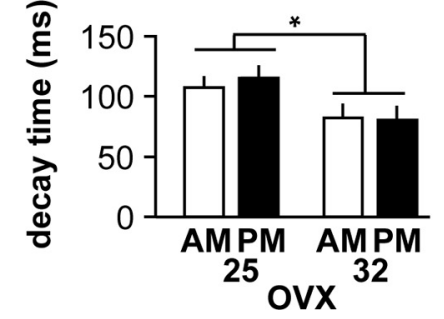

25C AM 25C PM OVX+E
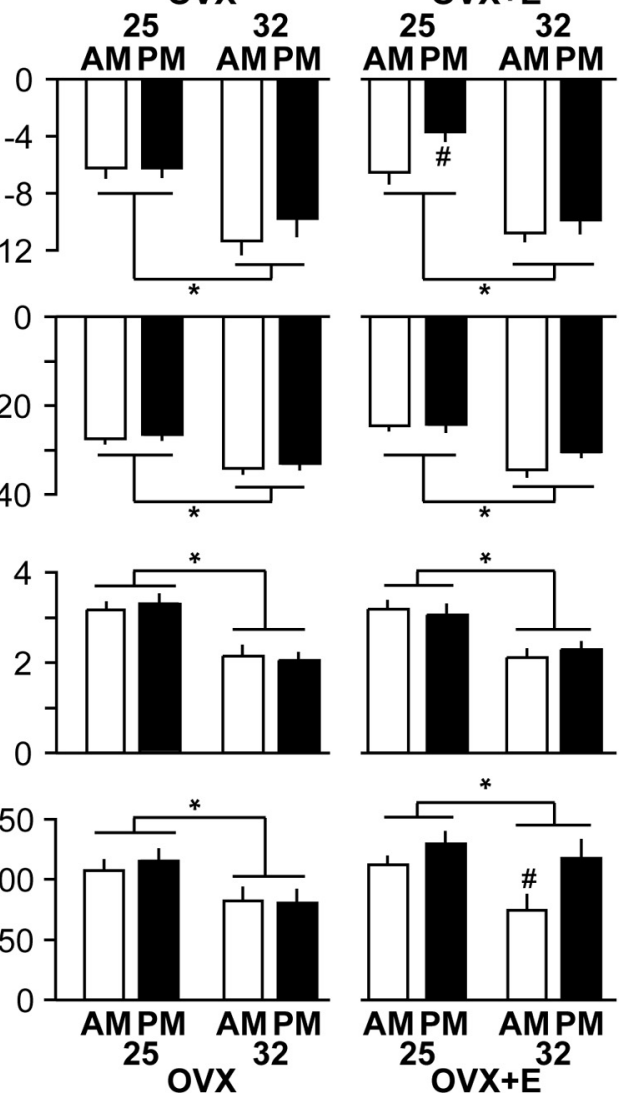

Figure 4. Temperature alters decay time and peak current but does not alter in vivo estradiol-dependent diurnal modulation of calcium current. $A-C$, Average maximal current (at $+10 \mathrm{mV}$ ) curve of cells from $0 \mathrm{VX}$ mice, $0 \mathrm{VX}+\mathrm{E}$ mice in A.M. and $0 \mathrm{VX}+\mathrm{E}$ mice in P.M., respectively, at 25 and $32^{\circ} \mathrm{C}$ (gray) and $25^{\circ} \mathrm{C}$ scaled to compare kinetics (scaled 25 ). $\boldsymbol{D}$, The amplitude of $I_{\mathrm{Ca}}$ is greater at $32^{\circ} \mathrm{C}$ than $25^{\circ} \mathrm{C}$ in cells from both OVX and OVX $+E$ mice, but estradiol-dependent effects persist at both temperatures. $\boldsymbol{E}, \boldsymbol{F}$, Mean \pm SEM effects of temperature on $V_{1 / 2 \text { act }}$ and $V_{1 / 2 \text { inact }}$ in cells from $0 V X$ and $0 V X+E$ mice in the A.M. and ( ${ }^{*} p<0.05,0 V X$ vs $O V X+E$; ${ }^{\#} p<0.05,0 V X+E$ A.M. vs OVX+E P.M.). $\boldsymbol{G}, \boldsymbol{H}$, Mean \pm SEM effects of temperature on rise time (10-90\%) and decay time $(90-50 \%)$ in cells from $\mathrm{OVX}$ and OVX+E mice in the A.M. and P.M. $\left({ }^{*} p<0.05,0 \mathrm{VX}\right.$ vs $\mathrm{OVX}+\mathrm{E}$; ${ }^{*} p<0.05, \mathrm{OVX}+\mathrm{E}$ A.M. vs OVX+EP.M.).

\section{Estradiol alters HVA-mediated current of GnRH neurons in a} diurnal manner

To study whether changes in calcium current $\left(I_{\mathrm{Ca}}\right)$ mediated via HVA channels are altered by estradiol feedback, $I_{\mathrm{Ca}}$ was recorded from GnRH neurons in slices made from OVX and OVX + E mice during the time of negative (A.M.) or positive (P.M.) feedback. Recordings were made at $32^{\circ} \mathrm{C}$, near the physiological temperature. In OVX mice, neither peak nor sustained components of the
HVA-mediated current were altered by time of day (Fig. $3 A, B$ ) (A.M., $n=16$; P.M., $n=16)$. In contrast, peak and sustained $I_{\mathrm{Ca}}$ density varied with time of day in cells from OVX $+\mathrm{E}$ mice, being significantly higher in the P.M. $(n=17)$ than in the A.M. $(n=17)$ at most membrane test potentials between -10 and $+50 \mathrm{mV}$ $(p<0.01)$. Furthermore, the peak $I_{\mathrm{Ca}}$ current density of GnRH neurons from $\mathrm{OVX}+\mathrm{E}$ mice was lower than that from OVX mice in the A.M., when estradiol exerts negative feedback (membrane potentials from -10 to $+40 \mathrm{mV} ; p<0.01 ; n=$ 16 OVX cells from 4 mice; $n=17$ OVX $+\mathrm{E}$ cells from 5 mice), and was higher than that from OVX mice in the P.M., when estradiol exerts positive feedback (membrane potentials, 0 and $10 \mathrm{mV}$; $p<0.05 ; n=16$ OVX cells from 4 mice; $n=17 \mathrm{OVX}+\mathrm{E}$ cells from 5 mice). The activation (Fig. 3C,E), steady-state inactivation (Fig. $3 D, F)$, rise time $(10-90 \%)$ (Fig. 3G), and membrane capacitance (data not shown) of GnRH neurons did not vary among the four groups. Interestingly, decay time (90-50\%) (Fig. 3H) of $\mathrm{GnRH}$ neurons from $\mathrm{OVX}+\mathrm{E}$ mice was higher in P.M. than in A.M. $(p<0.05)$; the prolonged current could contribute to increased excitability of GnRH neurons at this time. These results suggest that estradiol modulates HVA currents in GnRH neurons in a diurnal manner consistent with previously observed changes in GnRH neuronal activity (Christian et al., 2005).

\section{Estradiol modulates specific subtypes of HVA in GnRH neurons}

We next determined the subtypes of HVA altered by in vivo estradiol feedback. It is important in these longer duration recordings to minimize rundown, which we accomplished by recording at room temperature rather than more physiological temperatures. Most electrophysiological studies of VGCCs are done at room temperature. However, recent reports suggest temperature can substantially modify $I_{\mathrm{Ca}}$ in cardiac myocytes (Tsien et al., 1987), neurons (Acerbo and Nobile, 1994), muscle (Klöckner et al., 1990), and pituitary cells (Rosen, 1996). We thus first compared the properties of HVAmediated currents at $25^{\circ} \mathrm{C}$ (OVX A.M., $n=58$ cells from 15 animals; OVX P.M., $n=44$ cells from 14 animals; OVX +E A.M., $n=57$ cells from 16 animals; OVX $+\mathrm{E}$ P.M., $n=44$ cells from 15 animals) with measures made at $32^{\circ} \mathrm{C}$ (Fig. 3). Averaged traces of $I_{\mathrm{Ca}}$ recorded during a step to $+10 \mathrm{mV}$ (peak activation) from $-100 \mathrm{mV}$ are shown in Figure $4 A-C$ for cells from OVX mice, OVX $+\mathrm{E}$ mice in the A.M., and OVX $+\mathrm{E}$ mice in the P.M., respectively. In all models, recording at the lower room temperature reduced peak and sustained current am- 

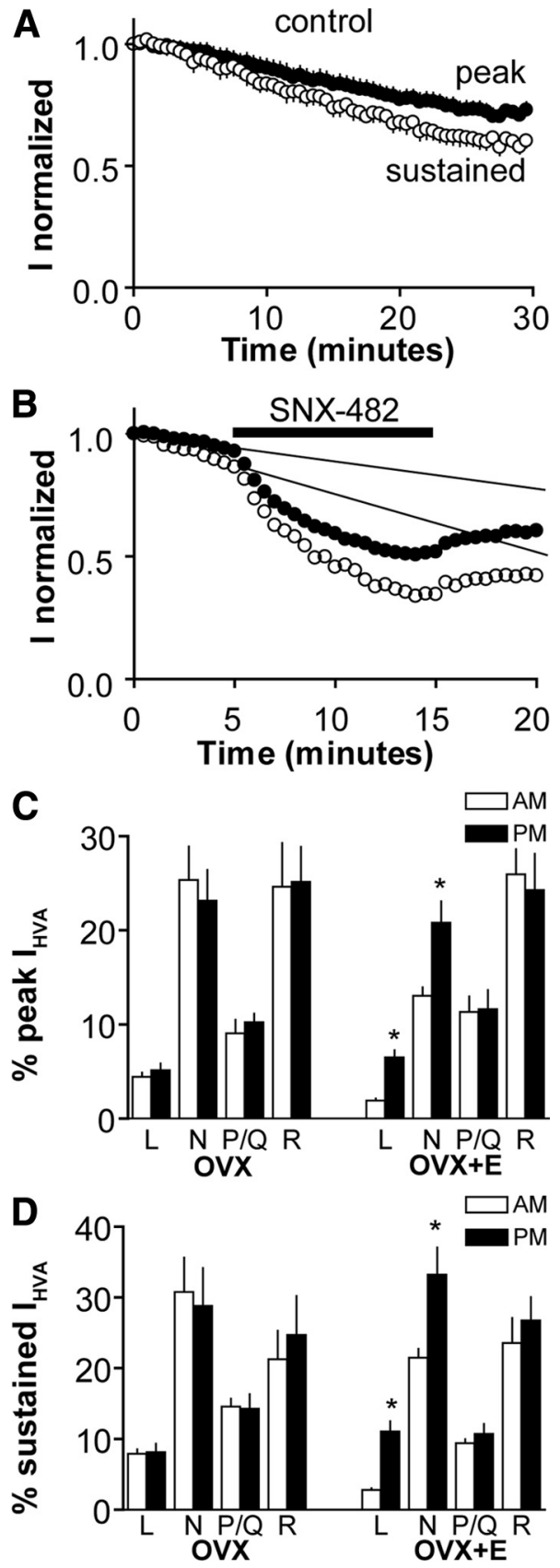

Figure 5. In vivo treatment with estradiol modulates specific subtypes of HVA calcium channels. $A$, Example of rundown of $I_{\text {Ca }}$ under control conditions. $B$, SNX-482 was locally applied for 10 min after a 5 min control period. The proportion of HVA subtype blocked by specific agents was assessed by the linear fit of the rundown during the first 5 min of control recording. $C, D$, The proportions of peak and sustained current of different subtype HVA from OVX and OVX+E mice in the A.M. and P.M. ( ${ }^{*} p<0.05$ A.M. vs P.M. in OVX+E mice). Error bars indicate SEM.

plitude (Fig. 4D) and current density (data not shown). A small but significant $(p<0.05)$ difference appeared between cells from OVX and OVX $+\mathrm{E}$ mice in $V_{1 / 2 \text { act }}$; at $25^{\circ} \mathrm{C}$, estradiol depolarized this potential but had no effect at $32^{\circ} \mathrm{C}$ (Fig. $4 E$ ). Because this effect disappeared as physiological temperatures were approached, it is likely of little impact on GnRH neurons in vivo. Importantly, the membrane potential at which current amplitude was maximum (data not shown), and the main effects of estradiol to reduce macroscopic HVA-current in the A.M. during negative feedback relative to that in cells from OVX mice and to increase current in the P.M. during positive feedback were repro- duced at $25^{\circ} \mathrm{C}(p<0.05$ for both at $10 \mathrm{mV}$ step) (Fig. $4 D)(p<$ $0.05)$.

We thus made recordings at $25^{\circ} \mathrm{C}$ to study which subtypes of VGCCs are modulated by estradiol using a pharmacological approach with specific channel blockers. To minimize recording duration and further reduce rundown, current was recorded only at $+10 \mathrm{mV}$ test pulse; membrane potential was held at $-60 \mathrm{mV}$ between trials, which consisted of a $-100 \mathrm{mV}$ prepulse for $250 \mathrm{~ms}$ and followed by a test pulse at $+10 \mathrm{mV}$ for $250 \mathrm{~ms}$ at $30 \mathrm{~s}$ intervals. The current was stabilized within $\sim 5 \mathrm{~min}$ of achieving the whole-cell configuration, after which it ran down $\sim 30 \%$ over 30 min (Fig. 5A). A representative experiment using SNX-482 to block R-type channels is shown in Figure $5 B$. Response to each blocker was calculated from the linear fit of rundown as shown. In cells from OVX mice (Fig. $5 C, D$, left), the peak and sustained components of macroscopic $I_{\mathrm{Ca}}$ contributed by channel subtypes were not different between A.M. and P.M. (from 28 animals; nitrendipine, L-type antagonist, $n=7$ in A.M., $n=6$ in P.M.), conotoxin GVIA (N-type antagonist, $n=6$ each in A.M. and P.M.), agatoxin IVA (P/Q-type antagonist, $n=6$ each in A.M. and P.M.), and SNX-482 (R-type antagonist, $n=8$ in A.M., $n=$ 7 in P.M.). In contrast, in cells from OVX $+\mathrm{E}$ mice (Fig. $5 C, D$, right), the peak and sustained components of macroscopic $I_{\mathrm{Ca}}$ conducted via L- and N-type channels were greater in the P.M. during positive feedback than in the A.M. during negative feedback ( $p<0.05 ; n=6$ in both A.M. and P.M. for both channel subtypes). There was no difference in the proportion of current conducted via P/Q- ( $n=6$ in both A.M. and P.M.) or R-type $(n=$ 9 in A.M., $n=8$ in P.M.) channels between A.M. and P.M. These results suggest in vivo treatment with estradiol modulates specific subtypes of VGCCs in GnRH neurons.

\section{Rapid effects of estradiol on $I_{\mathrm{Ca}}$ in $\mathrm{GnRH}$ neurons}

There is increasing evidence that estradiol can also rapidly modulate neuronal function by changing ion channel activity (Mermelstein et al., 1996; Lee et al., 2002; Ullrich et al., 2007; Zhao and Brinton, 2007; Sarkar et al., 2008), including in GnRH neurons (Temple et al., 2004; Abe and Terasawa, 2005; Abe et al., 2008; Romanò et al., 2008; Chu et al., 2009). We thus studied whether there are rapid, nongenomic effects of estradiol on HVA-mediated currents in GnRH neurons. We used a similar design to that used for the study of HVA subtypes above (Fig. 5). After stabilization of $I_{\mathrm{Ca}}$ for 5-10 $\mathrm{min}$, and $5 \mathrm{~min}$ of control recording, $17 \beta$-estradiol was bath-applied for $15 \mathrm{~min}$, followed by washout for $10 \mathrm{~min} .17 \beta$-Estradiol rapidly (within $5 \mathrm{~min}$ ) and reversibly (washout within $5 \mathrm{~min}$ ) potentiated $I_{\mathrm{Ca}}$ in both A.M. and P.M.; there was no difference based on time of day, and data were pooled for analysis (Fig. 6A,B). Cells were classified as responding if there was a $\geq 20 \%$ change in peak $I_{\text {Ca. }}$. Vehicle had no effect $(0.1 \%$ ethanol; $n=8)$ (Fig. $6 C)$. The percentage of responsive neurons increased with increasing estradiol concentration ( $100 \mathrm{pm}, n=13 ; 1 \mathrm{nM}, n=14$ cells; $100 \mathrm{~nm}, n=6$ cells) (Fig. $6 C$ ). The stereoisomer $17 \alpha(100 \mathrm{~nm})$ elicited a $20 \%$ change in peak $I_{\mathrm{Ca}}$ in only one cell, indicating stereo-specificity (Mermelstein et al., 1996; Lee et al., 2002) and suggesting the increase in response was not attributable to changes in membrane fluidity induced by intercolation of estradiol into the membrane (data not shown) ( $n=$ 6). Although the percentage of responding cells increased with greater estradiol concentrations, the percentage change in $I_{\mathrm{Ca}}$ did not vary with concentration of estradiol (range, 20-24\% increase in peak current, $32-37 \%$ increase in sustained current). This suggests the ability of GnRH neurons to respond to acutely applied estradiol may be "all or none" (the exception to this is the re- 
A

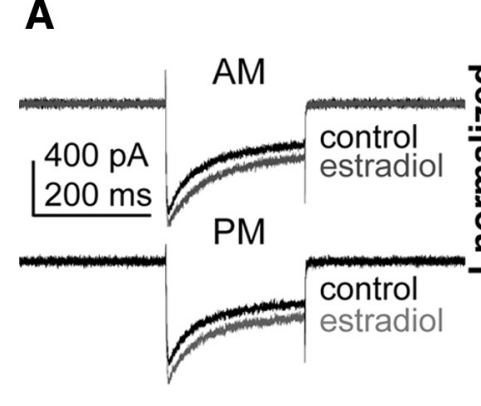

C
B

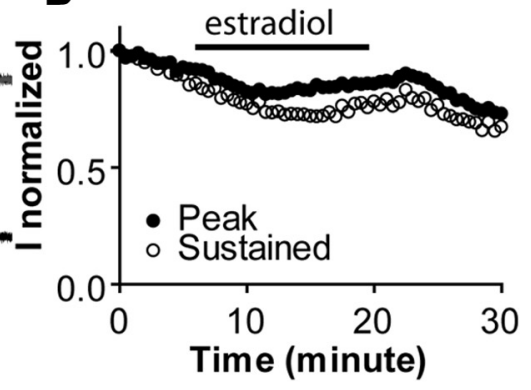

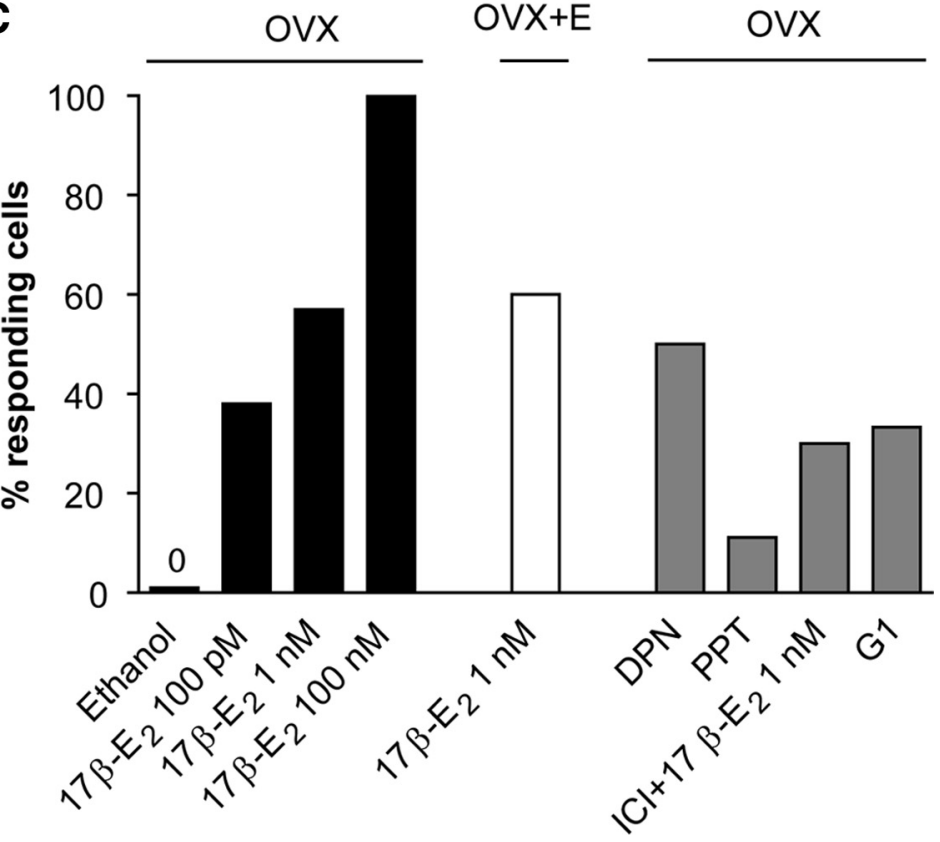

Figure 6. In vitro treatment with estradiol rapidly increases $I_{C \mathrm{C}}$ through classical receptor $\operatorname{ER} \beta$ and GPR30. $A$, Representative traces show estradiol (1 nm; gray) rapidly increases $I_{C_{a}}$ in $\mathrm{GnRH}$ neurons from $0 \mathrm{VX}$ mice in both the A.M. and P.M. $\boldsymbol{B}$, Time course of the rapid effect of estradiol $(1 \mathrm{~nm})$ on $I_{C \text { a }}$. $C$, The percentage of cells responding to estradiol with a rapid change in $I_{C^{2}}$. Black bars, Cells from OVX mice treated with vehicle or estradiol $17 \beta$; white bar, cells from 0VX + E mice treated with $1 \mathrm{~nm}$ estradiol $17 \beta$; gray bars, cells from OVX mice treated with specific receptor agonists and antagonists.

sponse to G1 discussed below). Because the percentage of cells responding to estradiol is the primary factor affected, we focused on this measure.

The above studies were done in OVX mice, raising the question of whether or not acutely applied estradiol alters $I_{\mathrm{Ca}}$ in cells that were recently exposed to estradiol in vivo. To test this, we repeated aspects of the above study and found that $1 \mathrm{~nm}$ estradiol has a similar effect in GnRH neurons in cells from OVX $+\mathrm{E}$ mice $(n=10)$ (Fig. 6C) as that observed in slices from OVX mice in terms of percentage of cells responding, magnitude of response, and the lack of effect of time of day on the response.

We next investigated the type of receptor mediating the rapid potentiation of $I_{\mathrm{Ca}}$ in $\mathrm{GnRH}$ neurons (Fig. 6C). The effect of estradiol was mostly mimicked by the ER $\beta$ agonist DPN (10 nM; $n=10)$, but not by the ER $\alpha$ agonist PPT (10 nM; $n=9)$. Interestingly, the classical receptor antagonist ICI $182780(1 \mu \mathrm{M})$ reduced (from 57 to $38 \%$ ) but did not eliminate the ability to respond to $1 \mathrm{~nm}$ estradiol ( $n=10$ cells), suggesting a second pathway may exist in addition to ER $\beta$. ICI itself had no effect on $I_{\mathrm{Ca}}(n=6)$ (data not shown). With regard to alternative pathways, we studied the effect of G1, an agonist for the putative Gprotein-coupled estrogen receptor GPR30 (Prossnitz et al., 2008). G1 (100 nM) increased $I_{\mathrm{Ca}}$ in $33 \%$ of cells $(n=4$ of 12

cells), similar to the percentage that responded to $17 \beta$-estradiol in the presence of ICI 182780. Of note, the increase in $I_{\mathrm{Ca}}$ in response to $\mathrm{G} 1$ was more robust than for estradiol, suggesting it may be a superagonist or have additional targets not related to estradiol signaling. These data suggest that $17 \beta$-estradiol increases $I_{\mathrm{Ca}}$ through classical estradiol receptor ER $\beta$ and membrane GPR30.

We next examined the subtypes of HVA channels that respond to acutely applied $17 \beta$-estradiol in GnRH neurons (Fig. 7A). Preincubation with the L-type VGCC blocker nitrendipine $(50 \mu \mathrm{M})$ reduced the percentage of cells responding to $1 \mathrm{~nm} 17 \beta$-estradiol ( $n=10$ cells). Addition of the N-type VGCC blocker conotoxin GIVA $(1 \mu \mathrm{M})$ was not different from nitrendipine itself ( $n=7$ cells), suggesting $17 \beta$-estradiol has no acute effect on N-type VGCCs. Furthermore, nitrendipine blocked the ability of DPN to increase $I_{\mathrm{Ca}}$ in GnRH neurons ( $n=9$ cells). These data suggest that $17 \beta$-estradiol potentiates L-type VGCCs through ER $\beta$. Next, we studied the subtypes of HVA activated by G1 in OVX mice. Since $17 \beta$-estradiol has no acute effect on N-type VGCCs (Fig. $7 A$ ), we tried to block the effects of G1 with L-, P/Q-, and R-type VGCCs blockers. Nitrendipine ( $n=11$ cells), SNX-482 ( $1 \mu \mathrm{M} ; n=10$ cells), and agatoxin IVA (200 $\mu \mathrm{M} ; n=10$ ) did not change the percentage of $\mathrm{GnRH}$ neurons responding to G1 (Fig. 7B). Interestingly, unlike other agents tested, in which the percentage increase in $I_{\mathrm{Ca}}$ was consistently in the same range, the R-type blocker SNX-482 reduced the percentage increase in $I_{\mathrm{Ca}}$ that was induced by G1 (Fig. 7C, percentage increase shown relative to control values so that no change in $I_{\mathrm{Ca}}$ is shown as $\left.0 \%\right)(n=4$ of 12 responding cells; $p<0.05$ ). Because the response to $\mathrm{G} 1$ was greater than that to estradiol, we confirmed no current was induced by G1 in the presence of cadmium $(400 \mu \mathrm{M})($ Fig. $7 B)(n=$ 8 ), indicating the G1-activated current was indeed mediated by calcium channels or calcium entry-sensitive mechanisms. These data suggest that $17 \beta$-estradiol potentiates R-type VGCCs through GPR30.

Finally, we applied both nitrendipine and SNX-482 to brain slices from OVX and OVX $+\mathrm{E}$ mice to confirm the above results. In both animal models, the combination of nitrendipine and SNX-482 essentially blocked the effect of $17 \beta$-estradiol with both the percentage of responding cells and the percentage change in current reduced below 10\% $(n=10$ OVX; $n=11$ OVX + E) (Fig. $7 D)$. Together, these data suggest $17 \beta$-estradiol rapidly potentiates $I_{\mathrm{Ca}}$ via multiple pathways initiated by ligand binding to $\mathrm{ER} \beta$ and/or GPR30, and that L-type and R-type calcium channels are the respective targets of this acute modulation.

\section{Discussion}

Estradiol feedback regulation of GnRH release is a key component generating the female reproductive cycle. Hormone release 
A
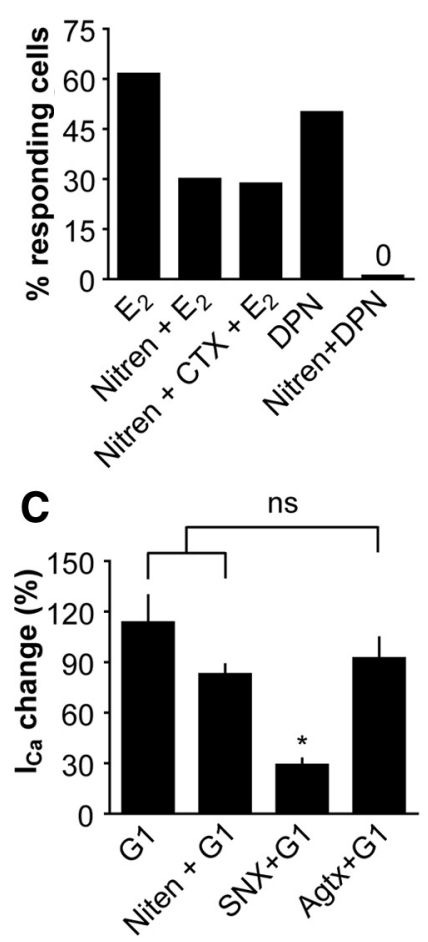

B

D

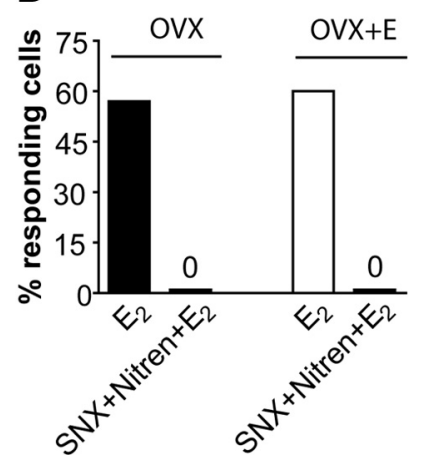

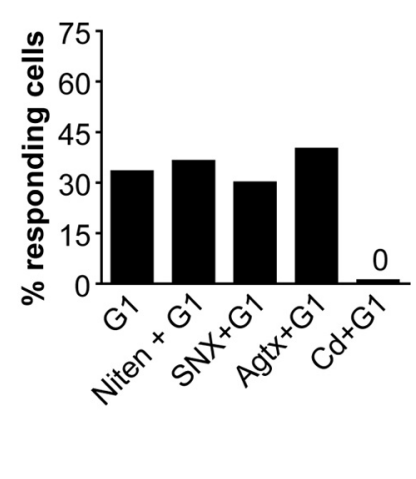

Figure 7. In vitro treatment with estradiol potentiates different subtypes of HVA through different receptors. $\boldsymbol{A}$, Nitrendipine $(50 \mu \mathrm{m})$ decreased the percentage of cells responding to estradiol ( $1 \mathrm{~nm}$ ). Additional treatment with conotoxin GVIA ( $700 \mathrm{~nm}$ ) did not change percentage of cells responding. Nitrendipine $(50 \mu \mathrm{m})$ blocked the effect of DPN (10 nм). $\boldsymbol{B}$, Nitrendipine $(50 \mu \mathrm{m})$, SNX (1 $\mu \mathrm{m})$, or agatoxin IVA (166 nm) did not block the effect of $\mathrm{G} 1$ (100 nM). SNX-482 (1 $\mu \mathrm{m})$ did not change the percentage of cells responding to $\mathrm{G} 1$ (100 nm). C, SNX-482 decreased the percentage increase in $I_{\mathrm{Ca}}$ in response to $\mathrm{G} 1{ }^{*} p<$ $0.05 ; 0 \%$ indicates no difference from control conditions). $D$, The combined application of nitrendipine and SNX-482 blocked the effect of $17 \beta$-estradiol in both OVX and OVX $+\mathrm{E}$ mice. Error bars indicate SEM.

and neuronal excitability are calcium dependent, and VGCCs are a main pathway for calcium influx. Here, we report estradiol modulates different HVA subtypes of VGCCs in GnRH neurons via different estrogen receptors and mechanisms.

Reports of LVA-mediated currents in GnRH neurons have varied with species, model, and developmental stage (Bosma, 1993). Several explanations may account for these differences. First, $\mathrm{Ca}_{\mathrm{V}} 3$ subunits that comprise LVA channels may be expressed by only some GnRH neurons (Zhang et al., 2009b). $\mathrm{GnRH}$ neurons are often divided into subpopulations by both gene expression (Smith et al., 2000) and function (Christian and Moenter, 2007; Chen and Moenter, 2009). Second, localization of $\mathrm{Ca}_{\mathrm{V}} 3$ message and protein can be somewhat different; this may be methodological but may indicate not all cells with abundant message translate it to similar levels of protein (McKay et al., 2006). Third, current from LVA channels in distal processes may dampen before arrival at the cell body, precluding accurate measurements at the soma. Such currents may impact on neuronal excitability; recent physiological and anatomical work suggests GnRH neurons may couple via dendrodendritic bundling (Roberts et al., 2008; Campbell et al., 2009). Fourth, LVA channels may be regulated as a critical part of steroid feedback. An estradiol replacement paradigm different from that used in the present study increased LVA-mediated T-type currents in GnRH neurons in models of both negative and positive feedback; however, increased excitability was only observed during positive feedback (Zhang et al., 2009b). That estradiol regimen involves an injection to mimic the proestrous increase, which, although more physiological with regard to pattern of steroid, makes diurnal changes difficult to interpret as they may be attributable to steroid level or time of day. Here, in a model exhibiting daily switches between estradiol negative and positive feedback in a constant estradiol milieu, no changes in LVA-mediated current with estradiol or time of day were observed, indicating the higher estradiol level is needed for this regulation.

LVA channels can play an important role in regulating firing patterns and oscillatory behavior because they require only a small depolarization from rest to open (Perez-Reyes, 2003; Molineux et al., 2006). In brain slices, individual GnRH neurons exhibit burst firing and episodic activity (Suter et al., 2000b; Kuehl-Kovarik et al., 2002; Nunemaker et al., 2003a) that could underlie the pulsatile secretion observed in vivo that is critical for fertility (Knobil et al., 1980). Although the amplitude of the current was low in the present study, LVA-mediated currents generated rebound spikes and may contribute to burst firing. GnRH neurons have high input resistance; thus, even small currents can substantially alter membrane potential (Suter et al., 2000a; Sim et al., 2001; DeFazio and Moenter, 2002; Chu and Moenter, 2006). Furthermore, cells expressing this current could play a role in initiating burst activity and communicating it to the balance of the GnRH neuronal network.

In this model, there was no effect of estradiol or time of day on LVA current. In contrast, HVA currents may play a role in mediating estradiol-dependent diurnal changes in $\mathrm{GnRH}$ neuron activity. Specifically, HVA-mediated current did not change with time of day in OVX mice, whereas in vivo estradiol treatment reduced HVA-mediated currents during estradiol negative feedback but increased these currents during positive feedback. These results reveal a novel mechanism for feedback modulation of GnRH neurons by estradiol in that an intrinsic property of these neurons is targeted, in addition to synaptic transmission (Mahesh et al., 1999; Han et al., 2004; Christian and Moenter, 2007, 2008a,b; Clarkson et al., 2008; Roseweir et al., 2009). Although these changes may be subsequent to alterations in estradiol-sensitive neuromodulation of GnRH neurons, for example by VIP (Harney et al., 1996; Smith et al., 2000, 2005; Christian and Moenter, 2008a) or kisspeptin (Smith et al., 2005; Pielecka-Fortuna et al., 2008) rather than estradiol action directly at the GnRH neuron, they suggest that multiple aspects of GnRH neuron physiology are targeted by the normal cyclical switch between estradiol negative and positive feedback.

The effects of in vivo estradiol on HVA-mediated currents specifically altered L- and N-type channels. L-type channels are typically found on cell bodies where they contribute to calciumdependent gene transcription (Gomez-Ospina et al., 2006). In contrast, N-type channels are found in dendrites, soma, and nerve terminals, and their opening mediates calcium-dependent release of neurotransmitters (Westenbroek et al., 1992; Reid et al., 2003; Catterall et al., 2005).

In addition to long-term changes in cell physiology brought about by the action of estradiol as a modulator of transcription, estradiol can alter the intrinsic and synaptic physiology of neurons within minutes (Kelly et al., 1976, 1977; Mermelstein et al., 1996; Lee et al., 2002; Zhao and Brinton, 2007; Sarkar et al., 2008). In GnRH neurons, estradiol at high physiological or pharmacological levels acutely increases firing activity (Abe and Terasawa, 2005; Chu et al., 2009) and increases frequency of oscillations in 
intracellular calcium concentration (Temple et al., 2004; Abe et al., 2008; Romanò et al., 2008).

In the present study, estradiol rapidly $(<5 \mathrm{~min})$ increased HVA-mediated calcium currents in GnRH neurons regardless of time of day and regardless of the estradiol condition of the animal. Rapid estradiol effects were mimicked by the ER $\beta$ agonist DPN, consistent with the expression of ER $\beta$ in GnRH neurons (Herbison and Pape, 2001) and other rapid effects of estradiol in GnRH neurons (Abrahám et al., 2003; Chu et al., 2009). The pure classical estrogen receptor antagonist ICI 182780, however, only partially blocked the acute effects of estradiol, suggesting other receptors may participate (Toran-Allerand et al., 2002; Roepke et al., 2009). GPR30, a candidate estrogen receptor (Prossnitz et al., 2008), is expressed in primate GnRH neurons and is involved in the rapid effect of estradiol on GnRH release and intracellular calcium oscillations (Noel et al., 2009). Here, the GPR30 agonist G1 rapidly increased HVA currents in one-third of GnRH neurons, suggesting a subpopulation may express GPR30. Of interest, G1 elicited an even greater response than estradiol. One explanation is that supraphysiological levels of estradiol are needed to fully activate GPR30; such concentrations may be locally available within the brain (Corpéchot et al., 1981; ToranAllerand et al., 2005). As the G1-induced change in current is eliminated by cadmium, the ultimate target does appear to be calcium channels, or mechanisms dependent on an influx via these channels. Acute actions of estradiol were mediated by ER $\beta$ and GPR30, which increased L- and R-type currents, respectively.

The different effects of estradiol on HVA subtypes when given in vivo versus in vitro suggest different mechanisms are involved. Importantly, because the rapid actions of estradiol appear similar in both OVX and OVX $+\mathrm{E}$ animals, these changes may be additive in their regulation of GnRH neurons. In this regard, the longer time course of in vivo estradiol treatment enables mechanisms including changes in message and protein levels. Estradiolsensitive afferents may be engaged (Wintermantel et al., 2006; Heldring et al., 2007). For example, estradiol might interact with the circadian pacemaker in the suprachiasmatic nuclei, changing calcium channel function of GnRH neurons via VIP (Harney et al., 1996; Smith et al., 2000; Christian and Moenter, 2008b) or vasopressin (Palm et al., 1999). In vivo estradiol might also change HVA-mediated current through changes in signaling via metabotropic receptors for GABA or glutamate (Chu and Moenter, 2005; Dumalska et al., 2008; Zhang et al., 2009a). GABAergic (Christian and Moenter, 2007) and glutamatergic (Christian et al., 2009) transmission indeed change with time of day in this model in an estradiol-dependent manner; thus, the afferent signal is present. In contrast to in vivo estradiol, acutely applied estradiol is thought to reveal nongenomic mechanisms. Physiologically, an acute change in estradiol may come from a burst of local synthesis, but such mechanisms remain speculative (Woolley, 2007). Acute estradiol likely acts directly on the GnRH neuron itself or via rapid changes in neuromodulation. Because both action potential generation and ionotropic receptors for GABA and glutamate were blocked in the present studies, these acute effects of estradiol are likely directly on the GnRH neuron. This interpretation is supported by the lack of any diurnal changes in response to acutely applied estradiol, as opposed to the well documented time-of-day-dependent changes that occur in response to estradiol in vivo (Moenter et al., 2009). This latter observation suggests the acute estradiol signal is not interacting with the circadian pacemaker in the suprachiasmatic nucleus under these experimental conditions.
The present study shows two novel pathways by which estradiol can modulate VGCCs in GnRH neurons. The effects of both in vivo and in vitro suggest that estradiol has multiple effects on VGCCs. These data provide a new link between estradiol and $\mathrm{GnRH}$ neuron function. Estrogen changes intrinsic properties in addition to synaptic transmission and other neuromodulators to regulate GnRH neuron activity for female reproductive success. Determining the underlying signal pathways of estradiol modulation on VGCCs will be important to understand the central neural control of reproduction.

\section{References}

Abe H, Terasawa E (2005) Firing pattern and rapid modulation of activity by estrogen in primate luteinizing hormone releasing hormone-1 neurons. Endocrinology 146:4312-4320.

Abe H, Keen KL, Terasawa E (2008) Rapid action of estrogens on intracellular calcium oscillations in primate luteinizing hormone-releasing hormone-1 neurons. Endocrinology 149:1155-1162.

Abrahám IM, Han SK, Todman MG, Korach KS, Herbison AE (2003) Estrogen receptor $\beta$ mediates rapid estrogen actions on gonadotropinreleasing hormone neurons in vivo. J Neurosci 23:5771-5777.

Acerbo P, Nobile M (1994) Temperature dependence of multiple high voltage activated $\mathrm{Ca}^{2+}$ channels in chick sensory neurones. Eur Biophys J 23:189-195.

Barry PH (1994) JPCalc, a software package for calculating liquid junction potential corrections in patch-clamp, intracellular, epithelial and bilayer measurements and for correcting junction potential measurements. J Neurosci Methods 51:107-116.

Batra S (1987) Increase by oestrogen of calcium entry and calcium channel density in uterine smooth muscle. Br J Pharmacol 92:389-392.

Bosma MM (1993) Ion channel properties and episodic activity in isolated immortalized gonadotropin-releasing hormone $(\mathrm{GnRH})$ neurons. J Membr Biol 136:85-96.

Bourguignon JP, Gerard A, Debougnoux G, Rose J, Franchimont P (1987) Pulsatile release of gonadotropin-releasing hormone $(\mathrm{GnRH})$ from the rat hypothalamus in vitro: calcium and glucose dependency and inhibition by superactive GnRH analogs. Endocrinology 121:993-999.

Campbell RE, Gaidamaka G, Han SK, Herbison AE (2009) Dendrodendritic bundling and shared synapses between gonadotropin-releasing hormone neurons. Proc Natl Acad Sci U S A 106:10835-10840.

Catterall WA, Perez-Reyes E, Snutch TP, Striessnig J (2005) International Union of Pharmacology. XLVIII. Nomenclature and structure-function relationships of voltage-gated calcium channels. Pharmacol Rev 57:411-425.

Chen P, Moenter SM (2009) GABAergic transmission to gonadotropinreleasing hormone $(\mathrm{GnRH})$ neurons is regulated by $\mathrm{GnRH}$ in a concentration-dependent manner engaging multiple signaling pathways. J Neurosci 29:9809-9818.

Christian CA, Moenter SM (2007) Estradiol induces diurnal shifts in GABA transmission to gonadotropin-releasing hormone neurons to provide a neural signal for ovulation. J Neurosci 27:1913-1921.

Christian CA, Moenter SM (2008a) Vasoactive intestinal polypeptide can excite gonadotropin-releasing hormone neurons in a manner dependent on estradiol and gated by time of day. Endocrinology 149:3130-3136.

Christian CA, Moenter SM (2008b) Critical roles for fast synaptic transmission in mediating estradiol negative and positive feedback in the neural control of ovulation. Endocrinology 149:5500-5508.

Christian CA, Mobley JL, Moenter SM (2005) Diurnal and estradioldependent changes in gonadotropin-releasing hormone neuron firing activity. Proc Natl Acad Sci U S A 102:15682-15687.

Christian CA, Pielecka-Fortuna J, Moenter SM (2009) Estradiol suppresses glutamatergic transmission to gonadotropin-releasing hormone neurons in a model of negative feedback in mice. Biol Reprod 80:1128-1135.

Chu Z, Moenter SM (2005) Endogenous activation of metabotropic glutamate receptors modulates GABAergic transmission to gonadotropinreleasing hormone neurons and alters their firing rate: a possible local feedback circuit. J Neurosci 25:5740-5749.

Chu Z, Moenter SM (2006) Physiologic regulation of a tetrodotoxinsensitive sodium influx that mediates a slow afterdepolarization potential in gonadotropin-releasing hormone neurons: possible implications for the central regulation of fertility. J Neurosci 26:11961-11973. 
Chu Z, Andrade J, Shupnik MA, Moenter SM (2009) Differential regulation of gonadotropin-releasing hormone neuron activity and membrane properties by acutely applied estradiol: dependence on dose and estrogen receptor subtype. J Neurosci 29:5616-5627.

Clarkson J, d'Anglemont de Tassigny X, Moreno AS, Colledge WH, Herbison AE (2008) Kisspeptin-GPR54 signaling is essential for preovulatory gonadotropin-releasing hormone neuron activation and the luteinizing hormone surge. J Neurosci 28:8691-8697.

Corpéchot C, Robel P, Axelson M, Sjövall J, Baulieu EE (1981) Characterization and measurement of dehydroepiandrosterone sulfate in rat brain. Proc Natl Acad Sci U S A 78:4704-4707.

DeFazio RA, Moenter SM (2002) Estradiol feedback alters potassium currents and firing properties of gonadotropin-releasing hormone neurons. Mol Endocrinol 16:2255-2265.

Dumalska I, Wu M, Morozova E, Liu R, van den Pol A, Alreja M (2008) Excitatory effects of the puberty-initiating peptide kisspeptin and group I metabotropic glutamate receptor agonists differentiate two distinct subpopulations of gonadotropin-releasing hormone neurons. J Neurosci 28:8003-8013.

Dungan HM, Gottsch ML, Zeng H, Gragerov A, Bergmann JE, Vassilatis DK, Clifton DK, Steiner RA (2007) The role of kisspeptin GPR54 signaling in the tonic regulation and surge release of gonadotropin-releasing hormone/luteinizing hormone. J Neurosci 27:12088-12095.

Edwards DP (2005) Regulation of signal transduction pathways by estrogen and progesterone. Annu Rev Physiol 67:335-376.

Fukushima A, Sano A, Aiba S, Kimura F (2003) Role of $\mathrm{Na}^{+}$and $\mathrm{Ca}^{2+}$ channels in the preoptic LH surge generating mechanism in proestrous rats. Endocr J 20:145-153.

Giri M, Kaufman JM (1994) In vitro GnRH release from the isolated medial basal hypothalamus of the male guinea pig: evidence for the existence of two pools of releasable GnRH. Brain Res 648:270-280.

Gomez-Ospina N, Tsuruta F, Barreto-Chang O, Hu L, Dolmetsch R (2006) The $\mathrm{C}$ terminus of the L-type voltage-gated calcium channel CaV1.2 encodes a transcription factor. Cell 127:591-606.

Han SK, Todman MG, Herbison AE (2004) Endogenous GABA release inhibits the firing of adult gonadotropin-releasing hormone neurons. Endocrinology 145:495-499.

Haneda K, Oka Y (2004) Selective modulation of voltage-gated calcium channels in the terminal nerve gonadotropin-releasing hormone neurons of a teleost, the dwarf gourami (Colisa lalia). Endocrinology 145:4489-4499.

Harney JP, Scarbrough K, Rosewell KL, Wise PM (1996) In vivo antisense antagonism of vasoactive intestinal peptide in the suprachiasmatic nuclei causes aging-like changes in the estradiol-induced luteinizing hormone and prolactin surges. Endocrinology 137:3696-3701.

Heldring N, Pike A, Andersson S, Matthews J, Cheng G, Hartman J, Tujague M, Ström A, Treuter E, Warner M, Gustafsson JA (2007) Estrogen receptors: how do they signal and what are their targets? Physiol Rev 87:905-931.

Herbison AE, Pape JR (2001) New evidence for estrogen receptors in gonadotropin-releasing hormone neurons. Front Neuroendocrinol 22:292-308.

Hiruma H, Uemura T, Kimura F (1997) Neuronal synchronization and ionic mechanisms for propagation of excitation in the functional network of immortalized GT1-7 neurons: optical imaging with a voltage-sensitive dye. J Neuroendocrinol 9:835-840.

Jarvis SE, Zamponi GW (2007) Trafficking and regulation of neuronal voltage-gated calcium channels. Curr Opin Cell Biol 19:474-482.

Joëls M, Karst H (1995) Effects of estradiol and progesterone on voltagegated calcium and potassium conductances in rat CA1 hippocampal neurons. J Neurosci 15:4289-4297.

Johnson BD, Zheng W, Korach KS, Scheuer T, Catterall WA, Rubanyi GM (1997) Increased expression of the cardiac L-type calcium channel in estrogen receptor-deficient mice. J Gen Physiol 110:135-140.

Karsch FJ, Moenter SM, Caraty A (1992) The neuroendocrine signal for ovulation. Anim Reprod Sci 28:329-341.

Kato M, Ui-Tei K, Watanabe M, Sakuma Y (2003) Characterization of voltage-gated calcium currents in gonadotropin-releasing hormone neurons tagged with green fluorescent protein in rats. Endocrinology 144:5118-5125.

Kelly MJ, Moss RL, Dudley CA (1976) Differential sensitivity of preoptic- septal neurons to microelectrophoresed estrogen during the estrous cycle. Brain Res 114:152-157.

Kelly MJ, Moss RL, Dudley CA, Fawcett CP (1977) The specificity of the response of preoptic-septal area neurons to estrogen: 17alpha-estradiol versus 17beta-estradiol and the response of extrahypothalamic neurons. Exp Brain Res 30:43-52.

Klöckner U, Schiefer A, Isenberg G (1990) L-type Ca-channels: similar Q10 of Ca-, Ba- and $\mathrm{Na}$-conductance points to the importance of ion-channel interaction. Pflugers Arch 415:638-641.

Knobil E, Plant TM, Wildt L, Belchetz PE, Marshall G (1980) Control of the rhesus monkey menstrual cycle: permissive role of hypothalamic gonadotropin-releasing hormone. Science 207:1371-1373.

Krsmanović LZ, Stojilković SS, Merelli F, Dufour SM, Virmani MA, Catt KJ (1992) Calcium signaling and episodic secretion of gonadotropinreleasing hormone in hypothalamic neurons. Proc Natl Acad Sci U S A 89:8462-8466.

Krsmanović LZ, Mores N, Navarro CE, Tomić M, Catt KJ (2001) Regulation of $\mathrm{Ca}^{2+}$-sensitive adenylyl cyclase in gonadotropin-releasing hormone neurons. Mol Endocrinol 15:429-440.

Kuehl-Kovarik MC, Pouliot WA, Halterman GL, Handa RJ, Dudek FE, Partin KM (2002) Episodic bursting activity and response to excitatory amino acids in acutely dissociated gonadotropin-releasing hormone neurons genetically targeted with green fluorescent protein. J Neurosci 22:23132322.

Kurata K, Takebayashi M, Kagaya A, Morinobu S, Yamawaki S (2001) Effect of beta-estradiol on voltage-gated $\mathrm{Ca}^{2+}$ channels in rat hippocampal neurons: a comparison with dehydroepiandrosterone. Eur J Pharmacol 416:203-212.

Kusano K, Fueshko S, Gainer H, Wray S (1995) Electrical and synaptic properties of embryonic luteinizing hormone-releasing hormone neurons in explant cultures. Proc Natl Acad Sci U S A 92:3918-3922.

Lee DY, Chai YG, Lee EB, Kim KW, Nah SY, Oh TH, Rhim H (2002) 17Betaestradiol inhibits high-voltage-activated calcium channel currents in rat sensory neurons via a non-genomic mechanism. Life Sci 70:2047-2059.

Legan SJ, Karsch FJ (1975) A daily signal for the LH surge in the rat. Endocrinology 96:57-62.

Mahesh VB, Zamorano P, De Sevilla L, Lewis D, Brann DW (1999) Characterization of ionotropic glutamate receptors in rat hypothalamus, pituitary and immortalized gonadotropin-releasing hormone $(\mathrm{GnRH})$ neurons (GT1-7 cells). Neuroendocrinology 69:397-407.

McKay BE, McRory JE, Molineux ML, Hamid J, Snutch TP, Zamponi GW, Turner RW (2006) $\mathrm{Ca}_{\mathrm{v}} 3$ T-type calcium channel isoforms differentially distribute to somatic and dendritic compartments in rat central neurons. Eur J Neurosci 24:2581-2594.

Mermelstein PG, Becker JB, Surmeier DJ (1996) Estradiol reduces calcium currents in rat neostriatal neurons via a membrane receptor. J Neurosci 16:595-604.

Miller BH, Olson SL, Levine JE, Turek FW, Horton TH, Takahashi JS (2006) Vasopressin regulation of the proestrous luteinizing hormone surge in wild-type and Clock mutant mice. Biol Reprod 75:778-784.

Moenter SM, Chu Z, Christian CA (2009) Neurobiological mechanisms underlying oestradiol negative and positive feedback regulation of gonadotrophinreleasing hormone neurones. J Neuroendocrinol 21:327-333.

Molineux ML, McRory JE, McKay BE, Hamid J, Mehaffey WH, Rehak R, Snutch TP, Zamponi GW, Turner RW (2006) Specific T-type calcium channel isoforms are associated with distinct burst phenotypes in deep cerebellar nuclear neurons. Proc Natl Acad Sci U S A 103:5555-5560.

Nilsson S, Mäkelä S, Treuter E, Tujague M, Thomsen J, Andersson G, Enmark E, Pettersson K, Warner M, Gustafsson JA (2001) Mechanisms of estrogen action. Physiol Rev 81:1535-1565.

Noel SD, Keen KL, Baumann DI, Filardo EJ, Terasawa E (2009) Involvement of G protein-coupled receptor 30 (GPR30) in rapid action of estrogen in primate LHRH neurons. Mol Endocrinol 23:349-359.

Norman RL, Blake CA, Sawyer CH (1973) Estrogen-dependent 24-hour periodicity in pituitary LH release in the female hamster. Endocrinology 93:965-970.

Nunemaker CS, DeFazio RA, Moenter SM (2002) Estradiol-sensitive afferents modulate long-term episodic firing patterns of $\mathrm{GnRH}$ neurons. Endocrinology 143:2284-2292.

Nunemaker CS, Straume M, DeFazio RA, MoenterSM (2003a) Gonadotropinreleasing hormone neurons generate interacting rhythms in multiple time domains. Endocrinology 144:823-831. 
Nunemaker CS, DeFazio RA, Moenter SM (2003b) Calcium current subtypes in GnRH neurons. Biol Reprod 69:1914-1922.

Palm IF, Van Der Beek EM, Wiegant VM, Buijs RM, Kalsbeek A (1999) Vasopressin induces a luteinizing hormone surge in ovariectomized, estradiol-treated rats with lesions of the suprachiasmatic nucleus. Neuroscience 93:659-666.

Patterson E, Ma L, Szabo B, Robinson CP, Thadani U (1998) Ovariectomy and estrogen-induced alterations in myocardial contractility in female rabbits: role of the L-type calcium channel. J Pharmacol Exp Ther 284:586-591.

Paxinos G, Franklin K (2001) The mouse brain in stereotaxic coordinates, Ed 2. New York: Academic.

Perez-Reyes E (2003) Molecular physiology of low-voltage-activated T-type calcium channels. Physiol Rev 83:117-161.

Pielecka-Fortuna J, Chu Z, Moenter SM (2008) Kisspeptin acts directly and indirectly to increase gonadotropin-releasing hormone neuron activity and its effects are modulated by estradiol. Endocrinology 149:1979-1986.

Prossnitz ER, Arterburn JB, Smith HO, Oprea TI, Sklar LA, Hathaway HJ (2008) Estrogen signaling through the transmembrane $G$ proteincoupled receptor GPR30. Annu Rev Physiol 70:165-190.

Reid CA, Bekkers JM, Clements JD (2003) Presynaptic $\mathrm{Ca}^{2+}$ channels: a functional patchwork. Trends Neurosci 26:683-687.

Roberts CB, Hemond P, Suter KJ (2008) Synaptic integration in hypothalamic gonadotropin releasing hormone $(\mathrm{GnRH})$ neurons. Neuroscience 154:1337-1351.

Roepke TA, Qiu J, Bosch MA, Rønnekleiv OK, Kelly MJ (2009) Cross-talk between membrane-initiated and nuclear-initiated oestrogen signalling in the hypothalamus. J Neuroendocrinol 21:263-270.

Romanò N, Lee K, Abrahám IM, Jasoni CL, Herbison AE (2008) Nonclassical estrogen modulation of presynaptic GABA terminals modulates calcium dynamics in gonadotropin-releasing hormone neurons. Endocrinology 149:5335-5344.

Rosen AD (1996) Temperature modulation of calcium channel function in GH3 cells. Am J Physiol 271:C863-C868.

Roseweir AK, Kauffman AS, Smith JT, Guerriero KA, Morgan K, PieleckaFortuna J, Pineda R, Gottsch ML, Tena-Sempere M, Moenter SM, Terasawa E, Clarke IJ, Steiner RA, Millar RP (2009) Discovery of potent kisspeptin antagonists delineate physiological mechanisms of gonadotropin regulation. J Neurosci 29:3920-3929.

Sarkar SN, Huang RQ, Logan SM, Yi KD, Dillon GH, Simpkins JW (2008) Estrogens directly potentiate neuronal L-type $\mathrm{Ca}^{2+}$ channels. Proc Natl Acad Sci U S A 105:15148-15153.

Sim JA, Skynner MJ, Herbison AE (2001) Heterogeneity in the basic membrane properties of postnatal gonadotropin-releasing hormone neurons in the mouse. J Neurosci 21:1067-1075.

Smith JT, Cunningham MJ, Rissman EF, Clifton DK, Steiner RA (2005) Regulation of Kiss1 gene expression in the brain of the female mouse. Endocrinology 146:3686-3692.

Smith MJ, Jiennes L, Wise PM (2000) Localization of the $\mathrm{VIP}_{2}$ receptor protein on GnRH neurons in the female rat. Endocrinology 141:43174320.

Spergel DJ (2007) Calcium and small-conductance calcium-activated potassium channels in gonadotropin-releasing hormone neurons before, during and after puberty. Endocrinology 148:2383-2390.

Suter KJ, Song WJ, Sampson TL, Wuarin JP, Saunders JT, Dudek FE, Moenter SM (2000a) Genetic targeting of green fluorescent protein to gonadotropin-releasing hormone neurons: characterization of whole-cell electrophysiological properties and morphology. Endocrinology 141:412-419.

Suter KJ, Wuarin JP, Smith BN, Dudek FE, Moenter SM (2000b) Whole-cell recordings from preoptic/hypothalamic slices reveal burst firing in gonadotropin-releasing hormone neurons identified with green fluorescent protein in transgenic mice. Endocrinology 141:3731-3736.

Swandulla D, Armstrong CM (1989) Calcium channel block by cadmium in chicken sensory neurons. Proc Natl Acad Sci U S A 86:1736-1740.

Temple JL, Laing E, Sunder A, Wray S (2004) Direct action of estradiol on gonadotropin-releasing hormone-1 neuronal activity via a transcriptiondependent mechanism. J Neurosci 24:6326-6333.

Toran-Allerand CD, Guan X, MacLusky NJ, Horvath TL, Diano S, Singh M, Connolly ES Jr, Nethrapalli IS, Tinnikov AA (2002) ER-X: a novel, plasma membrane-associated, putative estrogen receptor that is regulated during development and after ischemic brain injury. J Neurosci 22:83918401.

Toran-Allerand CD, Tinnikov AA, Singh RJ, Nethrapalli IS (2005) $17 \alpha$-Estradiol: a brain-active estrogen? Endocrinology 146:3843-3850.

Tsien RW, Fox AP, Hess P, McCleskey EW, Nilius B, Nowycky MC, Rosenberg RL (1987) Multiple types of calcium channel in excitable cells. Soc Gen Physiol Ser 41:167-187.

Ullrich ND, Koschak A, MacLeod KT (2007) Oestrogen directly inhibits the cardiovascular L-type $\mathrm{Ca}^{2+}$ channel Cav1.2. Biochem Biophys Res Commun 361:522-527.

Van Goor F, Krsmanović LZ, Catt KJ, Stojilkovic SS (1999) Control of action potential-driven calcium influx in GT1 neurons by the activation status of sodium and calcium channels. Mol Endocrinol 13:587-603.

Van Goor F, LeBeau AP, Krsmanović LZ, Sherman A, Catt KJ, Stojilkovic SS (2000) Amplitude-dependent spike-broadening and enhanced $\mathrm{Ca}^{2+}$ signaling in GnRH-secreting neurons. Biophys J 79:1310-1323.

Watanabe M, Sakuma Y, Kato M (2004) High expression of the R-type voltage-gated $\mathrm{Ca}^{2+}$ channel and its involvement in $\mathrm{Ca}^{2+}$-dependent gonadotropin-releasing hormone release in GT1-7 cells. Endocrinology 145:2375-2383.

Westenbroek RE, Hell JW, Warner C, Dubel SJ, Snutch TP, Catterall WA (1992) Biochemical properties and subcellular distribution of an N-type calcium channel alpha 1 subunit. Neuron 9:1099-1115.

Wildt L, Marshall G, Knobil E (1980) Experimental induction of puberty in the infantile female rhesus monkey. Science 207:1373-1375.

Wintermantel TM, Campbell RE, Porteous R, Bock D, Gröne HJ, Todman MG, Korach KS, Greiner E, Pérez CA, Schütz G, Herbison AE (2006) Definition of estrogen receptor pathway critical for estrogen positive feedback to gonadotropin-releasing hormone neurons and fertility. Neuron 52:271-280.

Woolley CS (2007) Acute effects of estrogen on neuronal physiology. Annu Rev Pharmacol Toxicol 47:657-680.

Zhang C, Bosch MA, Levine JE, Rønnekleiv OK, Kelly MJ (2007) Gonadotropin-releasing hormone neurons express KATP channels that are regulated by estrogen and responsive to glucose and metabolic inhibition. J Neurosci 27:10153-10164.

Zhang C, Bosch MA, Rønnekleiv OK, Kelly MJ (2009a) $\gamma$-Aminobutyric acid $B$ receptor mediated inhibition of gonadotropin-releasing hormone neurons is suppressed by kisspeptin-G protein-coupled receptor 54 signaling. Endocrinology 150:2388-2394.

Zhang C, Bosch MA, Rick EA, Kelly MJ, Ronnekleiv OK (2009b) $17 \beta$ Estradiol regulation of T-type calcium channels in gonadotropinreleasing hormone neurons. J Neurosci 29:10552-10562.

Zhao L, Brinton RD (2007) Estrogen receptor alpha and beta differentially regulate intracellular $\mathrm{Ca}^{2+}$ dynamics leading to ERK phosphorylation and estrogen neuroprotection in hippocampal neurons. Brain Res 1172: $48-59$. 